IBAD Sosyal Bilimler Dergisi

IBAD Journal of Social Sciences

dergipark.org.tr/ibad

IBAD, 2021; (11): 475-505

DOI: $10.21733 /$ ibad. 978870

Özgün Araştırma / Original Article

\title{
Uzaktan Eğitim Sürecinde Öğretmenlerin Yaşadığı Problemler: Sosyal Bilgiler Öğretmenleri Örneği
}

\section{Problems Faced By Teachers In The Process OfDistance Education: Case Of Social Studies Teachers}

Sevgi Coşkun Keskin ${ }^{1}$, Gökhan Şentürk² ${ }^{2}$, Mesut Ömer ${ }^{3}$, Recep Dursun ${ }^{4}$

\author{
* Sorumlu yazar \\ Corresponding author
}

${ }^{1}$ Prof.Dr., Sakarya Üniversitesi, Türkiye

Prof. Dr., Sakarya University, Turkey

scoskun@sakarya.edu.tr

ORCID ID https://orcid.org/0000-0001-2345-6789

${ }^{2}$ Sosyal Bilgiler Öğretmeni, T.C. Milli Eğitim Bakanlığı, Türkiye

Teacher, Ministry of National Education, Turkey

senturk55gokhan@gmail.com

ORCID ID https://orcid.org/0000-0003-1705-4147

${ }^{3}$ Sosyal Bilgiler Öğretmeni, T.C. Milli Eğitim Bakanlığı, Türkiye

Teacher, Ministry of National Education, Turkey

mesut.omer@ogr.sakarya.edu.tr

ORCID ID https://orcid.org/0000-0002-6668-413X

4Sosyal Bilgiler Öğretmeni, T.C. Milli Eğitim Bakanlığı, Türkiye

Teacher, Ministry of National Education, Turkey

recep.dursun@ogr.sakarya.edu.tr

ORCID ID https://orcid.org/0000-0002-7219-8453

Makale geliş tarihi / First received : 04.08.2021

Makale kabul tarihi / Accepted $\quad$ : 30.09.2021

Bilgilendirme / Acknowledgement:

Yazarlar aşağıdaki billgillen dirmeleri yapmaktadırlar:

1- Yazarların makaleye katkıları eşittir.

2- Makalenin yazarları arasında çıkar çatışması bulunmamaktadır.

3- Makalemizin etik kurulu izni Sakarya üniversitesi Etik Kurulu tarafından 08.07.2021 tarih ve E-61923333-050.9943178 sayılı yazısı ile alınmıştır.

4- Bu makalede araştırma ve yayın etiğine uyulmuştur.

This article was checked by intihal.net. Similarity Index 08\%

\section{Atıf bilgisi / Citation:}

Coşkun Keskin, S., Şentürk, G., Ömer, M., Dursun, R. (2021). Uzaktan eğitim sürecinde öğretmenlerin yaşadığ 1 problemler: Sosyal bilgiler öğretmenleri örneği. IBAD Sosyal Bilimler Dergisi, (11), 475-505. 


\section{ÖZ}

Covid-19, Çin'de ortaya çıkmış ve kısa sürede pandemiye dönüşmüştür. Salgının yayılımını azaltıak adına okullarda uzaktan eğitim sürecine geçilmiştir. Bu süreçte eğitimde bazı olumsuzluklar ile karşılaşılmıştır. $\mathrm{Bu}$ bağlamda araştırma; sosyal bilgiler öğretmenlerinin uzaktan eğitim sürecinde yaşadıkları problemler, problemlere buldukları çözüm yolları, sürecin ev ve aile hayatlarına etkisini ortaya koymayı amaçlamaktadır. Araştırmada nitel araştırma desenlerinden fenomenoloji kullanılmıştır. Araştırmanın çalışma grubunu 2020-2021 eğitim öğretim yılında Düzce, İstanbul ve Sakarya şehirlerinde farklı sosyo-ekonomik koşullara sahip devlet okullarında görev yapan 15 sosyal bilgiler öğretmeni oluşturmaktadır. Çalışma grubu belirlenirken amaçlı örneklem yöntemlerinden kolay ulaşılabilir durum ve ölçüt örnekleme kullanılmıştır. Araştırmada yarı yapılandırılmış görüşme formaları kullanılmıştır. Verilerin analizinde nitel içerik analizi kullanılmıştır. Araştırma sonucunda sosyal bilgiler öğretmenlerinin uzaktan eğitim sürecinde yaşadıkları problemleri öğrenci, veli, okul yönetimi ve öğretim süreci başlıklarında ifade ettikleri tespit edilmiştir. Yine uzaktan eğitim sürecinin ev ve aile düzenlerine etkisini de ebeveyn rolü, öğretmen eş, evin düzeni ve kendilerinin etkilenmesi başlıklarıyla ifade ettikleri görülmüştür.

\section{Anahtar kelimeler}

Sosyal bilgiler, Covid-19, uzaktan eğitim, karşılaşılan sorunlar

\section{ABSTRACT}

Covid-19 emerged from China and quickly turned into a pandemic. In order to reduce the spread of the pandemic, distance education process started at schools. In this process, some negative situations were encountered in education. In this context, the research aims to reveal the problems experienced by social studies teachers during the distance education process, the solutions they found for the problems and the effect of the process on their home and family lives. Phenomenology, one of the qualitative research designs, was used in the research. The study group of the research consists of 15 social studies teachers working at public schools with differen tsocio-economic conditions in the cities of Düzce, Istanbul and Sakarya in the 2020-2021 academic year. While determining the study group, convenince sampling and criterion sampling methods, which are the types of the purposeful sampling methods, were used. Semi-structured interview forms were used in the research. Qualitative content analysis was used in the analysis of the data. As a result of the research, it was determined that social studies teachers expressed the problems the yexperienced during the distance education process under the titles of students, parents, school management and teaching process. Besides, it was seen that they expressed the effect of distance education process on home and family lives under the titles of parental role, teacher spouse, layout of the house and affecting themselves.

\section{Keywords}

Social Studies, Covid-19, Distance Education, Problems Encountered 


\section{GíRiş}

Eğitim, geçmişi insanlık tarihi ile yaşıt olan, sahip olduğu dinamik yapısı gereği farklı şekillerde tanımlanan bir kavramdır. Tüm tanımlarda yer alan ortak noktalardan hareketle eğitim, bireyin yaşantılarını kullanarak toplumun isteklerine ve amaçlarına uygun olarak davranışlarını değiştirmeyi amaçlayan bir süreç olarak tanımlanabilir (Yavuz, 2018). Eğitim genel olarak informal ve formal eğitim olarak iki kısma ayrılmaktadır. İnformal eğitim içeriğine ailede ve çevrede gerçekleşen eğitimi alarak davranış değişikliğini gerçekleştirmeyi amçaçlamaktadır. Formal eğitim ise belirli bir amaca yönelik olarak, alanında profesyonel kişilerin rehberliğinde okulda ya da okul dişında çeşitli eğitim ortamlarında yapılan eğitimdir (Büyükkaragöz, Muşta, Yılmaz ve Pilten, 1997). Bu ayrım ise örgün eğitim ve yaygın eğitim kavramlarını ortaya çıkarmıştır. Örgün eğitim okul içerisinde ya da okul yerine geçecek kurumlarda çeşitli sınıf kademelerinde ve yaş gruplarında gerçekleşirken, yaygın eğitim ise okul çağı dişında kalan bireylere yönelik olarak eğitimlerini tamamlama veya bir beceri, hobi kazandırma amacıyla yapılan eğitimlerdir (Yavuz, 2018).

21.yy'da toplum, bireyler, bilginin kendisi ve teknoloji konularında meydana gelen değişimler eğitimin kendisinde de köklü yenilikleri doğurmuştur. Bu değişim süreci bireyin ihtiyaç ve beklentilerini karşılayabilmek için hayatın her alanında var olan, okulda ve okul dışında süregelen devamlı öğrenme kavramını doğurmuştur. Devamlı öğrenme kavramı ise bilgiye ulaşma ve bilgiyi kullanma konusunda kolaylıklar sunan eğitim teknolojisini ortaya çıkarmıştır (Alkan, 2011). Eğitim teknolojisi kavramı ilk ortaya çıtığında okulda gerçekleşen eğitimi destekleme, teknolojiyi okuldaki eğitime entegre etme anlamında kullanılmış olsa da teknolojinin gelişmesi ve insanlara ulaşılabilirliğinin artmasıyla birlikte geleneksel okulda aradığını bulamayan insanlar tarafından okuldaki eğitime alternatif olarak kullanılmaya başlanmasıyla uzaktan eğitim kavramı eğitim sistemi içerisinde yerini almıştır. Uzaktan eğitim kavramı, geleneksel eğitim yöntemlerinin yerine eğitim-öğretim sürecinin özel olarak hazırlanan öğretim üniteleri ve ortamlarda yürütülmesi olarak tanımlanabilmektedir (Demirel, 2020). Uzaktan eğitimde öğretim aracı olarak basılı kitaplar, görsel işitsel bantlar kullanılırken yayın yolu olarak ise radyo, televizyon, bilgisayar konferans görüşmeleri kullanılmaktadır. Uzaktan eğitim olgusu uzun bir süre özellikle yüksek öğretim aşamasında geliştirilen ve uygulanan bir sistem olarak kullanılırken 2019 pandemisi ile birlikte ise tüm eğitim kademelerinde tam zamanlı olarak uygulanan bir eğitim metodu halini almıştır.

Covid-19 pandemisi ile uzaktan eğitim sistemi büyük bir yayılım alanı bulmuştur. Birçok ülke salgının yayılmasını önleme tedbirleri kapsamında, hızlı bir planlama ile eğitim faaliyetlerini uzaktan eğitim sistemiyle sürdürmeye çalışarak eğitim öğretimde oluşabilecek kayıpların önüne geçmeyi amaçlamıştır. Türkiye'de de Covid-19 vakalarının görülmesi ve ardından Covid-19'a bağlı ölümlerin yaşanmaya başlaması nedeniyle tüm dünyada olduğu gibi bazı önlemler alınmıştır. Bu bağlamda alınan önlemlerden biri de hastalığın yayılmasını önlemek amacıyla bireylerin toplu olarak eğitim gördüğü okulların uzaktan eğitim sürecine başlamasıdır. Milli Eğitim Bakanlığı pandemi dönemi boyunca 15 Mart 2020 tarihi ile 01 Temmuz 2021 tarihleri arasında okulların yüz yüze eğitime ara vermesi ve sürecin uzaktan eğitimle devam etmesi ile ilgili toplamda 7 karar almıştır. Yine aynı tarihler arasında ölçme ve değerlendirme işlemlerininim yürütülmesi ile ilgili de 6 karar almış ve uygulamıştır. Bu doğrultuda Milli Eğitim Bakanlığı'na bağlı tüm eğitim kurumlarında 06-10 Nisan 2020 tarihlerinde uygulanacak olan ikinci ara tatilin 16-20 Mart 2020 tarihleri arasında uygulanmasi 
ve 23-27 Mart 2020 tarihleri arasında uzaktan eğitim yoluyla derslerin işlenişine devam edilmesi kararı alınmıştır (Milli Eğitim Bakanlığı [MEB], 2020). Alınan bu karar ile Türkiye Cumhuriyeti'nde Covid-19 hastalığına karşı uzaktan eğitim süreci resmen başlamıştır. Kararın alınması ile tüm okullarda örgün eğitime ara verilmiş ve uzaktan eğitim sürecine başlanmıştır. $\mathrm{Bu}$ süreçte öğretmenler tarafından süreç konusunda öğrencileri ve velileri bilgilendirmek, onlarla iletişimde kalmak amaciyla WhatsApp ve benzeri uygulamalar üzerinden sinıf grupları oluşturulmuştur. Öğretmenler oluşturulan sınıf grupları aracılığıyla veli ve öğrencilerin süreç ile ilgili sorularını cevaplamıştır. Ayrıca öğretmenler bu gruplar aracilığıyla, öğrencileri eğitim sürecinin içerisinde tutmak amacıyla ödevler ve etkinlikler paylaşmıştır. Covid-19 salgınının seyrine bağlı olarak Milli Eğitim Bakanlığı 27 Mart 2020 tarihinde başlaması gereken yüz yüze eğitim faaliyetlerini ertelemiş ve 30 Nisan 2020 tarihine kadar sürecin uzaktan eğitim ile yürütülmeye devam etmesine karar verilmiştir (MEB, 2020). Bu süreçte öğretmenler eğitim faaliyetlerini uzaktan eğitim yoluyla sürdürmeye devam etmişlerdir. Bu kapsamda Milli Eğitim Bakanlığı uzaktan eğitimin sağlıklı yürütülmesi, öğrencilerin eğitimin dışında kalmaması için ilkokul, ortaokul ve ortaöğretim düzeyinde kurduğu EBA TV kanalları aracılığıyla öğretmenlerle ders videoları hazırlayarak, her sınıf düzeyinde günlük ders programları oluşturup EBA TV aracılığıyla yayınlar yapmaya başlamıştır. Bu kapsamda yine Milli Eğitim Bakanlığı'nın aldığı karar doğrultusunda 8. sınıf derslerine giren öğretmenler internet üzerinden EBA uygulaması, Zoom, Skype gibi programlar aracılığılyla canlı ders eğitimine başlamışlardır. Uzaktan eğitim süreci bu şekilde ilerlerken Milli Eğitim Bakanlığ Covid-19 salgınının seyrini dikkate alarak uzaktan eğitim faaliyetlerini üçüncü kez 31 Mayıs 2020 tarihine kadar uzatmıştır (MEB, 2020). Bu süreçte de EBA TV aracılığıyla her gün belirlenen program dahilinde öğrencilere dersler verilmeye devam etmiştir. Bu duruma ek olarak 8. sinıflara uygulanan canlı dersler 5.,6. ve 7. sinıf düzeylerinde de uygulamaya başlanmıştır. Öğretmenler okul idarelerinin planlamaları doğrultusunda EBA altyapısını kullanarak canlı derslerini gerçekleştirmeye başlamışlardır. Canlı ders uygulamasının tüm sınıf düzeylerinde başlaması ile oluşan yoğunluk ve EBA altyapısının canlı ders uygulamasını ilk etapta kaldıracak düzeyde olmayışı gibi teknik nedenlerden dolayı derslere girişlerde problemler yaşanmıştır. Öte yandan aynı şekilde teknik problemler yaşayan öğrencilere destek olmaya çalışmışlardır. Bu bağlamda hem EBA'da oluşan yoğunluk hem de EBA üzerinden canlı ders için ayrılan zamanın kısıtlı olması nedeniyle öğretmenler, süreç içerisinde canlı derslerini EBA haricinde Zoom, Skype, Microsoft Teams gibi programlar aracilığıly da gerçekleştirmeye başlamışlardır. Covid-19 salgınının Türkiye'deki seyri dikkate alınarak Milli Eğitim Bakanlığı uzaktan eğitim sürecinidördüncü kez 2019-2020 eğitim öğretim yılının bitimi olan 19 Haziran 2020 tarihine kadar uzatmıştır (MEB, 2020). Bu süreçte de öğrenciler hem Bakanlık tarafından hazırlanan EBA TV üzerinden yayınlanan dersleri takip etmiş, hem de okul idaresi tarafından oluşturulan program doğrultusunda öğretmenlerinden canlı derslerini alarak uzaktan eğitim faaliyetlerini devam ettirmişlerdir. Yine Milli Eğitim Bakanlığı'nın aldığ1 karar doğrultusunda 2019-2020 eğitim öğretim yılının ikinci döneminde öğrencilerin not ile değerlendirilmesinin yapılmayacağı belirtilmiştir. 2019-2020 eğitim öğretim yılının ikinci dönemi Milli Eğitim Bakanlığı'nın aldığı karar doğrultusunda 15 Mart 2020 tarihinde uzaktan eğitim sürecine geçmiş ve 19 Haziran 2020 tarihine kadar süreç uzaktan eğitim ile devam etmiş ve öğrenciler 19 Haziran 2020 tarihinde yaz tatiline başlamışlardır. Yaz tatilinin bitimi ile 20202021 eğitim öğretim yılı, Milli Eğitim Bakanlığı'nın planlamaları doğrultusunda öğrencilerin 2019-2020 eğitim öğretim yılı ikinci döneminde uzaktan eğitimle aldıkları dönemin telafisi 
yapılarak başlamıştır. Bu kapsamda 31.08.2020 tarihinde başlayacak ve üç hafta sürecek uzaktan eğitim süreci gerçekleştirilmiştir (MEB, 2020). Bu süreçte öğretmenler derslerine girdikleri sınıflar ile 2019-2020 eğitim öğretim y1lında uzaktan eğitim sürecinde gördükleri derslerin telafisini gerçekleştirmişlerdir. Bu bağlamda 5. sınıfa yeni başlayan öğrenciler için de 5. sınıf dersine giren öğretmenler tarafından 4. sınıf müfredatı dikkate alınarak üç haftalık telafi programı hazırlanmış ve uygulanmıştır. Telafi programının tamamlanması ile birlikte salgının seyri dikkate alınarak 2020-2021 eğitim öğretim yılının 5.,6.,7. ve 8. sinıf düzeylerinde uzaktan eğitim ile başlaması kararlaştırılmıştır (MEB, 2020). Bu bağlamda 2020-2021 eğitim öğretim yılında olduğu gibi EBA TV yayınları ile öğrencilere ders içerikleri sunulmuş ve okul idarelerinin hazırlamış olduğu program doğrultusunda EBA üzerinden canlı ders uygulamasına başlanmıştır. Öğretmenler her sınıf düzeyinde okul idaresi tarafından kendilerine ayrılan ders saatlerinde canlı derslerini gerçekleştirmişlerdir. Öğrencilerin ise bu süreçte haftalık katılacakları ders saati 35 olarak belirlenmiştir. Süreç devam ederken 8 . sınıfların Lise Giriş Sınavı'na [LSG] hazırlanmaları ve salgının seyri dikkate alınarak yüz yüze eğitime başlamaları kararı alınmıştır (MEB, 2020). Alınan karar sınıfların ikiye bölünmesi ve oluşturulacak grupların haftada iki gün okula gelmeleri kaydıyla seyreltilmiş olarak uygulamaya geçirilmiştir. Karar doğrultusunda 8. sınıflar LGS'de sorumlu oldukları Türkçe, matematik, fen bilimleri, T.C. İnkılap Tarihi ve Atatürkçülük, din kültürü ve ahlak bilgilisi ile İngilizce derslerini okulda yüz yüze olarak işlemeye başlamış olup kalan derslerini uzaktan eğitim yoluyla işlemeye devam etmişlerdir. Bu kapsamda yine salgının seyri dikkate alınarak yeni bir okul türüne geçiş yapmaları nedeniyle 5. sınıflar da seyreltilmiş olarak yüz yüze eğitim faaliyetlerine başlamışlardır (MEB, 2020). Bu kapsamda 5. sınıf öğrencileri de Milli Eğitim Bakanlığı'nın belirlediği Türkçe, matematik, fen bilimleri, sosyal bilgiler, din kültürü ve ahlak bilgisi ile İngilizce derslerini okulda yüz yüze, diğer derslerini de uzaktan eğitim yolu ile almaya başlamışlardır. Diğer yandan 2020-2021 eğitim öğretim yılı birinci dönemine ait ölçme ve değerlendirme uygulamalarından yazılı sınavların tüm okullar tarafından gerçekleştirilmesi kararı alınmıştır (MEB, 2020). Yapılacak yazılı sınavlarda öğrencilerin uzaktan eğitim ile işledikleri derslerden de sınavda sorumlu olacakları belirtilmiştir. Bu doğrultuda salgının yayılmasına karşı önlemler alınarak okullar tarafından 2020-2021 eğitim öğretim yılı birinci dönemine ait birinci yazılı sınavlar kasım ayında gerçekleştirilmiştir. 2020 yılı kasım ayında salgının etkisini arttırmasıyla birlikte Milli Eğitim Bakanlığı tüm eğitim kademelerinde 04.01.2021 tarihine kadar uzaktan eğitim sürecine geçilmesine karar vermiştir (MEB, 2020). Bu süreçte seyreltilmiş olarak yüz yüze eğitime başlayan 5. ve 8. sinıflar da tüm derslerini uzaktan eğitim yoluyla işlemeye başlamıştır. Yine Milli Eğitim Bakanlığı'nın 25.12.2020 tarih ve 18443982 sayılıkararı uyarınca 2020-2021 eğitim öğretim yılı birinci dönemi için ölçme ve değerlendirme ile ilgili olarak yazılı sınav yapılmayacağı, yapılan sınavların geçersiz sayıldığı; öğrencilerin karne notlarının ders içi etkinlik notları ve varsa proje notları ile verileceği belirtilmiştir (MEB, 2020). 04.01.2021 tarihine gelindiğinde ise Türkiye'de salgının seyri dikkate alınarak uzaktan eğitim faaliyetlerinin 2020-2021 eğitim öğretim yılı birinci döneminin sona ereceği 22 Ocak 2021 tarihine kadar uzatıldığı açıklanmıştır (MEB, 2020). Bu açıklama ve alınan karar ile 2020-2021 eğitim öğretim yılı birinci dönemi 5. ve 8. sınıflarda kısa bir süre yüz yüze eğitim ve uzaktan eğitim süreci birlikte yürütülerek, 6. ve 7.sınıf düzeylerinde tamamen uzaktan eğitim yolu ile tamamlanmıştır.

15 Şubat 2021 tarihinde, 2020-2021 eğitim öğretim yılının ikinci dönemi; 8. sınıflar için sınıflar ikiye bölünmüş ve seyreltilmiş olarak yüz yüze bir şekilde; 5., 6. ve 7. sinıf düzeylerinde ise 
uzaktan eğitimle başlamıştır (MEB, 2021). 2020-2021 eğitim öğretim yılının 2. döneminde yapılacak yazılı sınavlar Milli Eğitim Bakanlığının aldığı karar doğrultusunda, Mart 2021'den Mayıs 2021'e ertelenmiştir. (MEB, 2021). Pandeminin Türkiye'deki seyri dikkate alınarak alınan karar doğrultusunda 7 Haziran 2021 tarihinden itibaren ortaokulların tüm kademelerinde sınıflar ikiye bölünerek seyreltilmiş bir şekilde yüz yüze eğitim faaliyetleri başlamıştır (MEB, 2021). Bu karar ile Mart 2020 tarihinden itibaren derslerini uzaktan eğitim ile işleyen 6. ve 7. sınıflar Mart 2020'den bu yana ilk defa okulda yüz yüze eğitime katılma imkânı bulmuşlardır. Yine Milli Eğitim Bakanlığı, aldığı karar ile 2020-2021 eğitim öğretim yılında ölçme ve değerlendirme işlemleri ile öğrencilerin 1. dönem karne notlarının 2. döneme geçmesi ve öğrencilerin okulda her dersten yazılı sınava girerek alacakları notların karne notu olarak belirlenmesi seçeneklerini sunmuş ve konu ile ilgili kararı velilere bırakmıştır (MEB, 2021). 2020-2021 eğitim öğretim yılı geneli uzaktan eğitim olmakla birlikte Haziran ayının son üç haftası yüz yüze eğitim faaliyetleri gerçekleştirilerek 02 Temmuz 2021 tarihinde sona ermiştir.

Uzaktan eğitim sürecinde yürütülen derslerden birisi de sosyal bilgiler dersidir. Sosyal bilgiler disiplinler arası bir anlayışla birçok disiplini öğrenciye sunmaktadır. İçeriğinde insanla ilgili her şeyi barındıran beşeri ve sosyal bilimler; tarih, coğrafya, ekonomi, sosyoloji, antropoloji, arkeoloji gibi disiplinleri kapsamaktadır (Keskin, 2020). Tarih anlayışı öğrenciye erdemli olmayı, coğrafi anlayış çevresel ve kültürel zekanın gelişmesini, ekonomi bir anlayış ise kaynakları verimli kullanmayı sağlar. Bundan dolayı sosyal bilgiler eğitimi önemlidir ve bu eğitim eksik kaldığında bireyin sosyal ve ahlaki gelişimi de eksik kalır (Parker, 2018). Geçmişten farklı olarak günümüz eğitim sisteminde öğrencilerin hazır bilgiyi alıp ezberleyen değil, bilgi kaynaklarına araştırarak ulaşan bireyler olması hedeflenmektedir (Yılar ve Tağrıkulu, 2020). 1973 tarih ve1739 sayılıTürk milli eğitim kanununa uygun olarak Sosyal bilgiler öğretim programı da; özgür bireyler olarak fiziksel ve duygusal özelliklerinin farkına varan, milli ve manevi değerleri özümseyen, Türkiye Cumhuriyeti'nin vatandaşı olarak ülkesini seven, haklarını ve sorumluluklarını bilip kullanabilen, eleştirel düşünme becerisine sahip olabilmek için doğru ve güvenilir bilgiye ulaşma yollarını bilen, temel iletişim becerilerini ve yöntemlerini kullanarak karşılaştı̆̆ı sorunlara çözüm getiren, demokratik bir değer olan katılımın önemine inanan, ülke ve dünya problemlerine karşı duyarlı bireyler yetiştirme amaçlarını taşımaktadır (MEB, 2018). Toplumsal yapıya uyum sağlayabilmesi hedeflenen bireyin kazanması gereken bilgi ve beceriler en çok sosyal bilgiler dersi sayesinde gerçekleşebilir (Erden, 1996).

Yukarıda da ifade edildiği gibi öğrencilerin sosyalleşmeleri ve topluma uyum sağlayabilmeleri adına oldukça önem arz eden sosyal bilgiler dersi de pandemi sürecinde çevrimiçi programlar aracılığıyla uzaktan işlenmiştir. Bu bağlamda 2019 yılı itibariyle başlayan ve tüm dünyayı etkisi altına alan, dünya tarihinde eşine az rastlanılan bir salgın olarak nitelendirilen Covid-19 pandemisi, günümüz dünyasında eğitimin zorunlu hale gelmesi ve eğitimden yararlanan insan sayının fazlalığı da göz önüne alındığında eğitim üzerinde büyük etki yaratmıştır. Yapılan literatür incelemesinde bu alanda pek çok çalışmanın yapıldığ çalışmalardan Balaman ve Tiryaki (2021), yaptıkları araştırma ile mecburi olarak yürütülen uzaktan eğitim çalışmalarına yönelik öğretmenlerin görüşlerini ortaya koymaya çalışırken, Kabapınar, Kanyılmaz, Ören Koçhan ve Atik (2021) ise öğretmenlerin ve velilerin gözünden öğrencilerin uzaktan eğitime katılımların öykülerini inceleyerek uzaktan eğitim mi, uzakta kalan eğitim mi? sorusuna cevap aramıştır. Yine yapılan çalışmalar incelendiğinde Avcı ve Akdeniz (2021) ile Kavuk ve Demirtaş (2021) yaptıkları çalışmada öğretmenlerin uzaktan 
eğitim sürecinde yaşadıkları problemleri ortaya çıkarmaya çalışmışlardır. Bazı araştırmacılar ise uzaktan eğitime ilişkin öğretmen görüşlerine yönelik çalışmalar yaparak bu sürecin eksiklerini, avantaj ve dezavantajlarını ortaya koymaya çalışmışlardır. Bu amaca yönelik olarak Fidan (2020) ve Kurt, Kandemir ve Çelik (2021) sınıf öğretmenleriyle çalışırken, Bakıoğlu ve Çevik (2020) ise fen bilimleri öğretmenleriyle çalışmışlardır. Akgül ve Oran (2020), ise yaptığı çalışmada sosyal bilgiler öğretmenlerinin uzaktan eğitime ilişkin görüşlerini ortaya çıkarmaya çalışmıştır. Öte yandan Yeşilyurt ve Dündar (2020) ile Ezer ve Aksüt (2021) uzaktan eğitim sürecinde kullanılan Eğitim Bilişim Ağ1 (EBA) sistemi özelinde sosyal bilgiler öğretmenlerinin görüşleri üzerine araştırma yapmışlardır. Seyhan (2021) ise yaptığ1 araştırmada sosyal bilgiler öğretmen adaylarının uzaktan eğitim sürecindeki deneyim ve algılarını araştıran bir çalışma ortaya koymuşlardır. Literatür incelemesi sonucunda yapılan bu araştırmanın sosyal bilgiler öğretmenlerinin uzaktan eğitim sürecinde yaşadıkları sorunlar ile bu sorunların ev ve aile düzenine etkisini ortaya koyması açısından önemli olduğu düşünülmektedir. Bu bağlamda araştırmada, uzaktan eğitim döneminde online ders veren sosyal bilgiler öğretmenlerinin görüşlerinden yola çıkarak, "Pandemi sürecinde Sosyal bilgiler öğretmenleri uzaktan eğitimde en çok hangi konularda problemler yaşamaktadır? Uzaktan eğitim süreci sosyal bilgiler öğretmenlerinin günlük yaşantılarını ve aile hayatlarını nasıl etkilemektedir?" sorularına cevap aranmiştır.

\section{YÖNTEM}

\section{Araştırma Modeli}

Araştırmada sosyal bilgiler öğretmenlerinin uzaktan eğitim sürecinde yaşadıkları problemler ve bu sürecin günlük yaşamları ile aile hayatlarına etkisinin ortaya çıkarılması amaçlanmaktadır. Bu amaç bağlamında, nitel araştırma yöntemlerinden fenomenoloji (olgu bilim) deseni kullanılmıştır. Fenomenoloji, tamamen yabancı olmadığımız, farkında olduğumuz ancak tam anlamıyla anlamlandıramadığımız olay ve durumları derinlemesine incelememizi sağlayan bir nitel araştırma desenidir (Yıldırım ve Şimşek, 2013). Bu desende gerçeklik bireysel bakış açılarında ve deneyimlerde aranır (Ersoy, 2016). Böylece araştırmacı tarafından, kişilerin tecrübelerini kendi bakış açılarıyla nasıl anlamlandırdıkları araştırılır (Baş ve Akturan, 2008). Fenomonoloji deseni kullanılarak yapılan çalışmalarla genellenebilir ve kesin sonuçlar ortaya konulamasa da bir durum ya da olayın daha iyi anlaşılmasına yardımcı olacak önemli veriler elde edilebilir. Bu anlamıyla da bu çalışmalar hem literatür hem de uygulama sahasına önemli katkılar sunabilir (Yıldırım ve Şimşek, 2013). Bu çalışmada da fenomen olarak alınan durum pandemi sürecindeki eğitimdir. Pandemi hem ülkemiz hem de dünya için yakın zamanlarda alışık olunmayan bir durum olup, eğitimi (sosyal bilgiler eğitimi sinırlılığında), nasıl etkilediği onu deneyimleyen öğretmenlerle derinlemesine görüşmeler yapılarak incelenmeye çalışılmıştır.

\section{Çalışma / Katılımcı Grubunun Belirlenmesi}

Fenomenoloji çalışmalarında kesin bir katılımcı sayısı olmamakla birlikte genel görüş bu tür çalışmalarda sonuca ulaşmak için uzun görüşmeler veya birden fazla görüşme seansları yapılabileceği için örnekleme katılan kişi sayısının sınırlı tutulması yönündedir (Yıldırım ve Şimsek, 2013). Bu bağlamda araştırmanın çalışma grubunu 2020-2021 eğitim-öğretim yılında Düzce, İstanbul, Sakarya şehirlerinde, farklı sosyo-ekonomik koşullara sahip devlet 
okullarında görev yapan 15 sosyal bilgiler öğretmeni oluşturmaktadır. Katılımcıların özellikleri Tablo 1'de açıklanmıştır.

Tablo 1. Çalışma/Katılımcı grubun özellikleri

\begin{tabular}{llll}
\hline Katılımc1 & Görev yaptı̆̆ şehir & Kıdem & Kullandı̆̆1 Dijital Platform \\
\hline Ö1 & İstanbul & 8 yıl & Microsoft Teams, Eba \\
\hline Ö2 & İstanbul & 13 yıl & Zoom, Eba, Microsoft Teams \\
\hline Ö3 & İstanbul & 10 yıl & Zoom, Eba \\
\hline Ö4 & İstanbul & 5 yıl & Zoom, Eba \\
\hline Ö5 & İstanbul & 9 yıl & Zoom, Eba \\
\hline Ö6 & Sakarya & 12 yıl & Zoom, Eba \\
\hline Ö7 & Sakarya & 9 yıl & Zoom, Eba \\
\hline Ö8 & Sakarya & 21 yıl & Zoom, Eba \\
\hline Ö9 & Sakarya & 19 yıl & Teamlink, Zoom, Eba \\
\hline Ö10 & Sakarya & 18 yıl & Skype, Google meet, Zoom, Eba \\
\hline Ö11 & Düzce & 11 yıl & Zoom, Eba \\
\hline Ö12 & Düzce & 19 yıl & Zoom, Eba \\
\hline Ö13 & Düzce & 9 yıl & Zoom, Eba \\
\hline Ö14 & Düzce & 8 yıl & Zoom, Eba \\
\hline Ö15 & Düzce & 8 y1l & Zoom, Eba \\
\hline
\end{tabular}

Araştırma grubuna katılan kişiler belirlenirken amaçlı örneklem yöntemlerinden kolay ulaşılabilir durum ve ölçüt örnekleme kullanılmıştır. Görüşme yapılan öğretmenler, pandeminin getirdiği kısıtlamalar nedeniyle araştırmacıların kolay ulaşabileceği çevrelerden seçilmiştir. Bu nedenle kolay ulaşılabilir durum örneklemesi kullanılmıştır. Bunun yanı sıra pandemi sürecinde çeşitli dijital programlar kullanarak aktif bir şekilde uzaktan eğitim yapan sosyal bilgiler öğretmenleri ölçüt alındığı için ölçüt örnekleme de yapılmıştır. Zira ölçüt örnekleme yöntemi çalışmaya dahil olan katılımcıların problemle ilgili olarak önceden belirlenmiş niteliklere sahip kişiler arasından seçilmesidir (Büyüköztürk, Akgün, Karadeniz, Demirel ve Kılıç Çakmak 2020). Bu araştırmada katılımcıların belirlenmesinde kullanılan ölçüt; katılımcıların Mart 2019'dan itibaren derslerini uzaktan eğitim yoluyla işleyen sosyal bilgiler öğretmenleri olmalarıdır.

\section{Veri Toplama Araçları, Veri Toplama Süreci ve Verilerin Analizi}

\section{Veri toplama aracının geliştirilmesi ve verilerin toplanması}

Çalışmada veri toplama aracı olarak yarı yapılandırılmış görüşme formu kullanılmıştır. Yarı yapılandırılmış görüşme formları çalışmada derinlemesine inebilme imkânı veren, katılımcıya kendisini rahatça ifade etme imkânı sağlayan bir görüşme yöntemidir (Patton, 2018). Sosyal bilgiler eğitimi alanında uzman görüşleri alınarak hazırlanan araştırma soruları, önce pilot uygulamaya tabi tutulmuş, pilot görüşmelerin incelenmesiyle sonda sorular eklenmiş ve görüşme soruları düzenlenerek görüşme formuna son şekli verilmiştir. $\mathrm{Bu}$ anlamda katılımcllara "Uzaktan eğitim sürecinde karşılaştığınız problemler (öğrenci, veli, okul yönetimi ve eğitim süreci boyutlarında) nelerdir? Örnek vererek açıklar mısınız?" ve "Uzaktan eğitim süreci günlük yaşamınızı ve aile hayatınızı nasıl etkiledi? Örnek vererek açıklar mısınız?" soruları yöneltilmiştir. 
Makalenin etik kurulu izni Sakarya üniversitesi Etik Kurulu tarafından 08.07.2021 tarih ve E61923333-050.99-43178 sayılı yazısı ile alınmıştır. Görüşmeler pandemi koşullarından dolayı telefon ve internet görüşmesi şeklinde yapılmıştır. Her bir katılımcı ile yaklaşık 30 dakikalık görüşmeler yapılmış, verilerin doğru şekilde aktarılması için katılımcıların izinleri alınarak görüşmeler kayıt altına alınmıştır. Verilerin analizi sırasında ihtiyaç duyulan durumlarda katılımcılara tekrar ulaşılarak görüşme formlarına eklemeler yapılmıştır. Bu sürelerle beraber araştırmada toplam yaklaşık 500 dakikalık görüşme yapılmıştır. Görüşmeler yazıya geçirildikten sonra katılımclara tekrar inceletilerek katılımcı teyidi sağlanmıştır. Araştırmanın veri toplama süreci aşamaları tablo 2' de gösterilmiştir.

Tablo 2. Veri Toplama Süreci

\begin{tabular}{lll}
\hline & Uygulama Aşaması & Uygulama Tarihi \\
\hline $\mathbf{1}$ & Görüşme sorularının hazırlanması & Ekim 2020 \\
\hline $\mathbf{2}$ & Pilot uygulama yapılması & Kasım 2020 \\
\hline $\mathbf{3}$ & Görüşme sorularına son şeklinin verilmesi & Kasım 2020 \\
\hline $\mathbf{4}$ & Katılımcı grubun belirlenmesi & Aralık 2020 \\
\hline $\mathbf{5}$ & Katılımcılar ile görüşmelerin yapılması & Aralık 2020/Ocak 2021 \\
\hline $\mathbf{6}$ & Görüşme ses kayıtlarının yazıya dökülmesi & Şubat 2021 \\
\hline
\end{tabular}

\section{Verilerin analizi}

Toplanan verilerin analizinde nitel içerik analizi kullanılmıştır. İçerik analizinde, toplanan verileri açılayabilecek kavramlara ve ilişkilere ulaşabilmek amacıyla veriler önce kavramsallaştırılmalı, daha sonra bu kavramlar mantıklı bir biçimde düzenlenerek veriyi açıklayan temalar ortaya çıkarılmalıdır (Yıldırım ve Şimşek, 2013). İçerik analizi veri işleme, verilerin kodlanması, tema oluşturma, verileri görsel hale getirme ve yorumlama aşamalarıyla gerçekleştirilmiştir.

Veri İşleme. Her bir öğretmene numara verilerek (Ö1, Ö2...Ö15) görüşme formları bilgisayar ortamına aktarılmıştır. Bu sürede yazıya dökülen içerikler defalarca okunarak kodlamaya zemin hazırlanmıştır.

Verileri Kodlama. İşlenen verilerde ön plana çıkan anlamlar kavram ya da kelimelere indirgenmiştir. Örneğin; "Ders sırasında bazı öğrencilerin dersi açık bırakıp ekran başından ayrıldığıı yaşadık. Kamera konusunda herhangi bir zorlama yapamadığımız için bu sıkıntıları yaşadım." söyleminden hareketle "başka işle meşgul olma" kodu çıkarılmıştır.

Tema Oluşturma. Ortaya çıkan kodlardan birbirine yakın olanlar bir araya getirilerek alt temalara, alt temalardan birbirine yakın olanlar bir araya getirilerek temalara ulaşılmıştır. Örneğin, "ders esnasinda ortamdan ses gelmesi" ve "ev içerisinde yaşanan sorunlar" kodları bir araya getirilerek "ortam ve fiziki ortamın uygun olmaması" alt teması oluşturulurken; "dersi sabıte etme" ve "ders esnasında yapılan yazışma" kodları bir araya getirilerek "disiplinsizlik" alt teması oluşturulmuştur. Bu adımdan sonra ise "ortam ve fiziki ortamın uygun olmaması" ve "disiplinsiliz" alt temaları bir araya getirilerek "öğrenci ile ilgili yaşanan problemler" temasına ulaşılmıştır.

Verileri görsel hale getirme. Oluşturulan kod ve temalar bağlamında verilerin rahat anlaşılması kolay yorumlanması amacıyla kavram haritaları oluşturulmuştur. 
Yorumlanma. Oluşturulan kavram haritalarındaki kod ve temalar yorumlanmış ve öğretmenlere ait söylem örnekleriyle ayrıntılı bir şekilde betimlenmiştir.

\section{Araştırmanın Geçerlilik ve Güvenilirliği}

Araştırma da inandırıcılığı (iç geçerlilik) artırmak için öğretmenlerin söylemleri tüm araştırmacılarla birlikte değerlendirilerek kodlar oluşturulmuş, kodlardan da ortak temalara ulaşılmıştır. Pandemi koşullarından dolayı araştırmacılar yüz yüze bir araya gelemedikleri zamanlarda sık sık online görüşmeler yaparak ortak bir yol izlemiştir. Fikir ayrılığına düşünülen konularda ise farklı bir uzmandan görüş alınmıştır. Bu durumu örnek vermek gerekirse; kodlar oluşturulurken katılımcıların sürecin kendilerine ve ailelerine etkisi ile ilgili yaşadıkları problemlerin hangi tema altında değerlendirileceği ile ilgili araştırmacılar arasında görüş ayrılığ1 yaşanmıştır. Konu ile ilgili uzman görüşüne başvurulmuş alınan görüş sonucu "ev ve aile düzeni" isimli yeni bir tema eklenmiştir. Yine araştırmanın iç geçerliliğini artırmak amacıyla da katılımcı teyidi/üye kontrolü (memberchecking) yapılarak katılımcılardan, araştırmanın ortaya koymadığı bulgular için sık sık geri dönütler alınmıştır. Üye kontrolü ya da katılımcı teyidi, katılımcıların araştırma sonuçlarını, kendi görüşlerini gerçekten ortaya koyup koymadıkları konusunda değerlendirme fırsatı sunmaktadır (Başkale, 2016). Araştırmanın dış geçerliliğinin sağlanması amacıyla da örneklem seçiminde amaçı örneklem yöntemlerinden ölçüt örnekleme kullanılmıştır. Ölçüt örnekleme ile araştırma sonuçlarının diğer kişi ve olaylara daha verimli şekilde aktarılmasının sağlanması amaçlanmıştır. Bu amaca yönelik olarak araştırmaya katılan katılımcılar olarak sosyal bilgiler öğretmenleri arasından pandemi sürecinin başlangıcından itibaren derslerini uzaktan eğitim yöntemiyle gerçekleştiren öğretmenler seçilmiştir. Öte yandan sık sık öğretmen söylemlerine yer verilerek çalışmanın güvenilirliği sağlanmaya çalışılmıştır.

\section{BULGULAR}

Pandemi sürecinde uzaktan eğitim veren sosyal bilgiler öğretmenleri yaşadıkları sorunları öğrenci, veli, okul yönetimi, öğretim süreci ile ev/yaşam ve aile düzeni temalarında değerlendirmişlerdir.

\section{Tema 1: Öğrenciyle ilgili problemler}

Katılımcılar öğrenciler ile yaşadıkları problemler teması altında yaşadıkları sorunları; derse katılmama/katılamama, disiplinsizlik, motivasyon düşüklü̈̆̈̈, iletişim kurma, ortam ve fiziki ortamın uygun olmaması alt temalarında ifade etmişlerdir. Alt temalar da kendi içinde kodlara ayrılmıştır. Aşağıda yer alan Şekil 1 bu durumu betimlemektedir. 
Şekil 1. Öğretmenlerin uzaktan eğitim sürecinde öğrenci kaynaklı yaşadıkları problemler

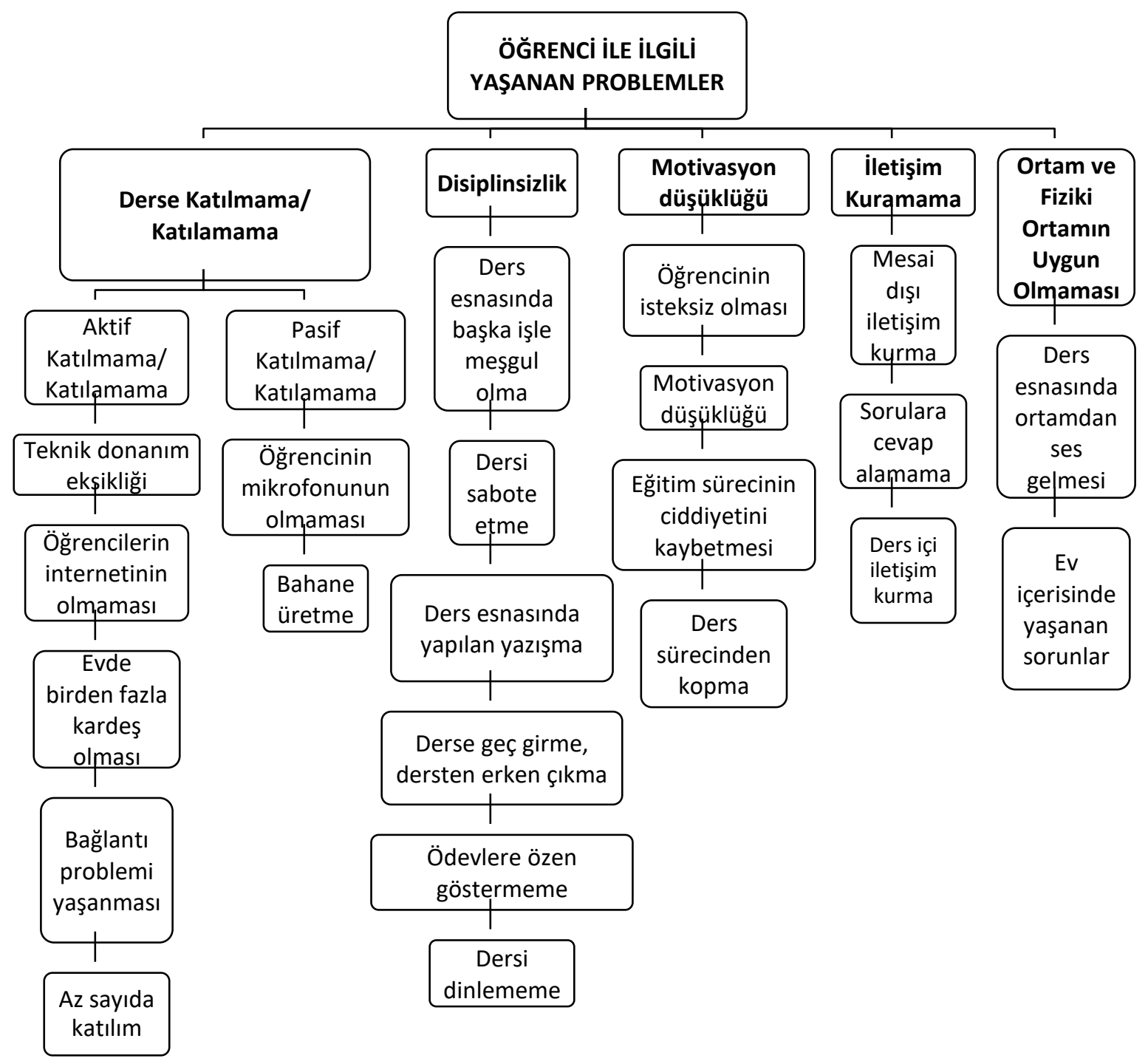

\section{Alt Tema 1: Derse Katılmama/Katılamama}

Sosyal bilgiler öğretmenleri bu konuyla ilgili yaşadıkları problemleri "aktif katılmama/katılamamave pasif katılmama/katılamama" olarak iki başlıkta belirtmişlerdir.

\section{Kod 1: Aktif katılmama/katılamama}

Aktif katılmama/katılamama bağlamında yaşanılan problemler; teknik donanım eksikliği, öğrencilerin internetinin olmaması, evde birden fazla kardeş olması, bağlantı problemleri yaşanması ve derse az sayıda öğrenci katılımı kaynaklıdır. Araştırmaya katılan öğretmenler uzaktan eğitim süreci başladığında bazı öğrencilerin canlı derslere katılmak için sahip olması gereken teknik imkânlardan yoksun olduğunu ifade etmişlerdir. Konu ile ilgili olarak Ö9 “Öğrencinin tableti var mı? Yok mu? Evinde elektrikler var mı? Yok mu? Veya öğrencinin internete ulaşım imkânı var mı? Bilmiyoruz. Dolayısıyla öğrenciyi derse katmak gibi bir zorunluluğumuz yok. Zorunluluğumuz yok derken zorlama anlamında yok, öğrencinin imkân durumu burada bizi kısıtllyor." diyerek düşüncesini belirtmiştir. Teknik araç gereç eksikliği yanında internet konusunda da öğrencilerin 
problemler yaşadığı belirtilmiştir. Konu ile ilgili olarak Ö1 “İnternete sahip olamayan öğrenci var, kotası dolan öğrenci var. Bu öğrenciler ayın belli döneminde derslere katılamadı." diyerek konu ile ilgili görüşünü dile getirmiştir. Evde birden fazla kardeş olması konusunda ise Ö3 "İnternet var ama öğrencinin bilgisayar ya da tableti o saatte kardeşi tarafindan kullanılıyor." diyerek yaşanan problemi ifade etmiştir. Uzaktan eğitim sürecinde bazı öğrencilerin bağlantı problemleri yaşadıkları belirtilmiştir. Yaşanan bağlantı problemleri ile ilgili olarak Ö5 “Öğrencilerle yaşadığımız problemlerin başında öğrencilerin de yaşadığı bağlantı problemleri oluyor. Özellikle bağlantı kuramayan öğrenciler bizimle iletişime geçtikleri için ders başladığında bazen onların da derse katılmasını sağlamaya çalışıyorum." diyerek bu konudaki yaşadığı güçlüğü dile getirmiştir. Öğrencilerin aktif katılamaması konusunda yaşanan problemlerden biri de uzaktan eğitim ile yapılan derslere öğrenci katılımının düşük olmasıdır. Bu konuda Ö2 “...okul ortamındaki gibi bütün öğrencilerin katılımının canlı derslerde să̆lanamamış olmasıydı. Bu da bütün öğrencilere ulaşma konusunda problem oluşturduğunu düşünüyorum." ifadesi ile öğrencilerin derse katılımlarının düşük olduğunu ifade etmiştir. Yine derse düşük katılım ile ilgili olarak Ö10 "En büyük problem tabii ki malumunuz 30 kişilik sinfflarda biz otuzu hiç yakalayamadık. Hep yirmilerde kaldık. 5. ve 6. sımıflarda bu sayı biraz artıyor ama 7. ve 8. sınıflarda yirmi sayısına ancak çıkabiliyoruz." demiştir. Araştırmaya katılan öğretmenlerden Ö15 de derslere sürekli aynı öğrencilerin katılım gösterdiğini "Sürekli aynı çocuklar katılıyor." cümlesi ile ifade etmiştir.

\section{Kod 2: Pasif katılmama/katılamama}

Pasif katılmama/katılamama bağlamında ise; öğrencinin mikrofonunun olmaması ve bahane üretme kaynaklı sorunların yaşanıldı̆̆1 ifade edilmiştir. Örneğin Ö11 "Sordŭ̆um sorulara cevap vermiyorlar, dersten düştük, mikrofon çalışmıyor gibi bahaneleri çok duyuyorum." diyerekbu konuyla ilgili düşüncelerini dile getirmişlerdir. Benzer şekilde Ö4 "Öğrencilerle diyalogumuz yüz yüze derslerde olduğu gibi olmuyor. Öğrenciler derse katılıyor ama bazı öğrenciler kameralarımı açmaya, mikrofon kullanmaya istekli olmuyorlar." söyleminde bulunmuştur. Ancak durumla baş etmenin yolu olarak Ö4 "Onları da ben söz vererek katılmaların sağhıyorum." şeklinde bir çözüm yolu bulduğunu ifade etmiştir.

\section{Alt Tema 2: Disiplinsizlik}

Diğer yandan sosyal bilgiler öğretmenleri, disiplinsizlik başlığı altında yaşadıkları problemleri; ders esnasında başka işle meşgul olma, dersi sabote etme, ders esnasında yapılan yazışma, derse geç girme dersten erken çıkma, ödevlere özen göstermeme, dersi dinlememe olarak ifade etmişlerdir. Öğrencinin ders esnasında başka işle meşgul olması konusunda Ö2 "Ders sırasında bazı öğrencilerin dersi açık bırakıp ekran başından ayrıldığını yaşadık. Kamera konusunda herhangi bir zorlama yapamadığımız için bu sıkıntıları yaşadım." şeklinde görüşünü belirtmiştir. Dersi sabote etme ile ilgili Ö6 "Canlı derslerde istedikleri gibi isimlerini değiştiriyorlar, farkl isimlerle giriyorlar. Öğrenci bu mu değil mi sürekli kontrol etme ihtiyacı duyuyorduk. Seslerini değiştiriyorlardı veya ders esnasında değişik sesler açıyorlardı." diyerek düşüncesini dile getirmiştir. Ders esnasında yapılan yazışmalar konusunda Ö9 "Öğrenci geliyor dersin çet [chat] bölümüne küfür yazıyor veya küfürlü konuşuyor." cümlesi ile yaşadığı sorunu ifade etmiştir. Bunların yanı sıra öğretmenler uzaktan eğitim ile yapılan derslerde öğrencinin derse giriş çıkışlarında kontrolün zayıf olduğunu öğrencinin dersin başlangıcında derse geç girdiğini ve ders devam ederken dersten ayrılan öğrenciler bulunduğunu belirtmişlerdir. Konu ile ilgili olarak Ö13 "Ders devam ederken öğrencilerden eksilmeler oluyor. Derse geç girme erken çıkma gibi olaylar oluyor. Bu durumda motivasyonu etkiliyor." demiştir. Ayrıca uzaktan eğitimle yapılan derslerde öğrencilerin sınıf 
ortaminda bulunmaması ve denetim dışında kalmaları nedeniyle dersi yeterince dinlemedikleri ve verilen ödevlere yeterince özen gösterilmediği araştırmaya katılan öğretmenler tarafından belirtilmiştir. Dersi dinlememe ve verilen ödevlere özen göstermeme konusunda Ö14 "Dersi dinlemiyorlar dinleyenlerinde tam olarak nasıl dinlediği belli değil. Ayrıca ödevlere özen göstermiyorlar." diyerek yaşadığı sorunu dile getirmiştir.

\section{Alt Tema 3: Motivasyon Düş̧üklüğ̈̈̈}

Sosyal bilgiler öğretmenleri öğrencilerin motivasyon ile ilgili problemlerini; öğrencinin isteksiz olması, motivasyon düşüklüğ̈̈, eğitim sürecinin ciddiyetini kaybetmesi, ders sürecinden kopma olarak ifade etmişlerdir. Katılımcılar uzaktan eğitim ile işledikleri derslerde öğrencilerin genel anlamda derslere karşı isteksiz bir tutum içerisinde olduklarını gözlemlediklerini belirtmişlerdir. Konu ile ilgili olarak Ö4 “Öğrenci açısından öğrencilerin bazılarının istekli olmaması bir problemdi." ifadesi ile yaşanılan durumu ifade etmiştir. Motivasyon düşüklüğü konusunda Ö13 "Öğrencilerin yatarak, uzanarak dersi dinlemesi motivasyonu düşürüyor." diyerek görüşünü dile getirmiştir. Uzaktan eğitimin ciddiyetini kaybetmesi konusunda Ö7 “Uzaktan eğitimi tatil olarak algllayan öğrencilerimiz var maalesef" cümlesi ile yaşanan sorunu ifade etmiştir. Uzaktan eğitim ile yapılan derslerde öğrencilerin ev ortamında sınıf ortamında olduğu gibi kendilerini derse veremediklerini ifade eden katılımcılar, bu nedenle bazı öğrencilerin ders esnasında dersi açarak ekran karşısından ayrılmak suretiyle ders sürecinden koptuklarını ifade etmişlerdir. Konu ile ilgili olarak Ö2 "Ders sırasında bazı öğrencilerin dersi açık bırakıp ekran başından ayrıldığııı yaşadık." diyerek yaşadığı problemi belirtmiştir.

\section{Alt Tema 4: Iletişim/ iletişim kuramama}

Araştırmaya katılan sosyal bilgiler öğretmenleri iletişim kurma konusunda yaşadıkları problemleri; mesai dışı iletişim kurmaya çalışma, sorulara cevap alamama ve ders içi iletişim kurma şeklinde belirtmişlerdir. Mesai dışı iletişim kurma konusunda Ö4 "İletişim olarak kullandığımız WhatsApp'ta öğrencilerin gerekli gereksiz her şeyi sormalar da bazen problem oluşturabiliyor." diyerek yaşadığı problemi ifade etmiştir. Katılımcılar uzaktan eğitim ortamında yaptıkları derslerde öğrencilerin sürece aktif katılımını sağlamak adına öğrencilere sorular sorduklarını fakat öğrencilerin sorulara cevap vermediğini belirtmişledir. Örneğin Ö10“Sorduğumuz sorulara bazen cevap alamıyoruz. Soru sorduğumda karşı tarafın sesi kapalı, kamerası kapalı teknik nedenlerden mi kapalı yoksa açmak mı istemiyor onu anlayamıyoruz." ifadesiyle yaşadığı problemi ifade etmiştir. Ders içi iletişim kurma konusunda araştırmaya katılan öğretmenler sosyal bilgiler dersinin içeriği itibariyle öğrencilerle ders esnasında sürekli iletişim halinde olunması gerektiğini belirtmişlerdir. Konu ile ilgili olarak Ö6 "Sosyal bilgiler sözel bir ders, öğrencinin konuşması gerekiyor." diyerek konu ile ilgili düşüncesini dile getirmiş olup ders içinde bu iletişimi sağlamak için "Bunun için mikrofonların özellikle açık tutmaların istiyorum." demiştir. Yine konu ile ilgili olarak Ö12 "Öğrencinin derse katılımını sağlamak gerekiyor." diyerek öğrenci ile ders içerisinde sürekli iletişim halinde olunmasının önemini vurgulamıştır. Ö12 ise "Ders esnasında yoklama alıyorum bazen de kamerası kapalı olanlara sorular sorarak aktif katılmalarm sağglıyorum." diyerek ders esnasında öğrenci ile sürekli iletişim halinde olduğunu belirtmiştir.

\section{Alt Tema 5: Ortam ve fiziki ortamin uygun olmaması}

$\mathrm{Bu}$ konuda sosyal bilgiler öğretmenleri yaşadıkları problemleri; ders esnasında ortamdan ses gelmesi, ev içerisinde yaşanan sorunlar olarak ifade etmişlerdir. Ders esnasında ortamdan ses gelmesi ile ilgili yaşadığı problemi Ö8 "Sıkça karşılaştı̆̆ımız bir problem de arka plandan sesler 
geliyor. Öğrencinin evi kalabalık, mikrofon açıldığı anda öğrenci iyi niyetli, derse katılmak istiyor fakat arka plandaki sesler nedeniyle karmaşa yaşanabiliyor." cümlesi ile ifade etmiştir. Ev içerisinde yaşanan sorunlar konusunda Ö8 "Arka planda bazen rahat olabiliyorlar. Çok fazla kamera açlmasa da açıldığında görüntüleri ve mikrofon açı olduğunda sesleri geliyor. Ders strasında bu sesleri duyarak evdeki bazı minik sorunlara da şahit olduğumuz oluyor." diyerek yaşadığı sorunu ifade etmiştir.

\section{Diğer}

Araştırmaya katılan sosyal bilgiler öğretmenlerinden Ö10 “Öğrenciler biliyorsunuz kaç aydan beri evin içerisinde ev dişında başka bir sosyal ortam göremediği için sosyal yönden, duygusal yönden doyurulması gerekiyor." diyerek sürecin öğrenciler üzerinde bıraktığı olumsuz psikolojik etki konusunda görüş bildirmiştir. Öğretmenlerden Ö11 ise "Öğrencilerde bilgilerin kalıcı olduğuna inanmıyorum." diyerek uzaktan eğitim sürecinin öğrenci üzerindeki olumsuz akademik etkisi konusunda düşüncesini ifade etmiştir.

\section{Tema 2: Veli ile ilgili problemler}

Araştırmaya katılan sosyal bilgiler öğretmenlerinden 11'i veliler ile ilgili sorunlar yaşadığını belirtirken 4 öğretmen ise veliler ile ilgili herhangi bir sorunla karşılaşmadıklarını belirtmişlerdir. Sosyal bilgiler öğretmenlerinin veliler ile ilgili sorunları 4 alt temada (fiziki ortamın düzenlenmemesinden kaynaklanan sorunlar, velilerin öğretmenlere belirlediği rol, ilgisiz davranma ve uzaktan eğitim süreciyle ilgili inançlar) sıralamışlardır. Alt temalar kendi içinde kodlara ayrılmaktadır. Veli ile ilgili problemler teması içerindeki alt temalar ve kodlar ile ilgili ayrıntılar Şekil 2'de sunulmuştur.

Şekil 2. Öğretmenlerin uzaktan eğitim sürecinde veli kaynaklı yaşadıkları problemler

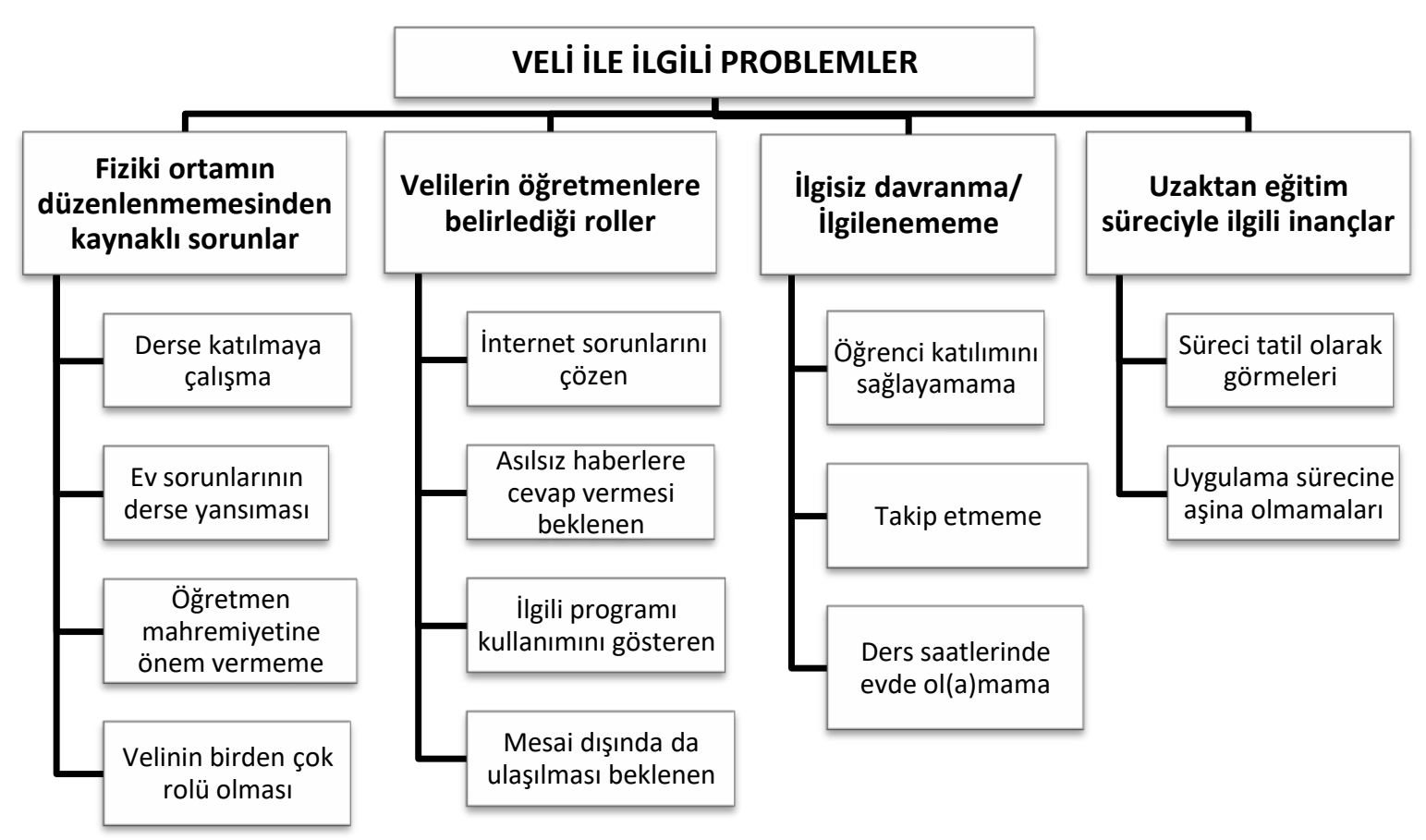


Alt Tema 1: Fiziki ortamın düzenlenmemesinden kaynaklı sorunlar. Öğretmenler, velilerin fiziki ortamı düzenlememesinden kaynaklı sorunlarını; derse katılmaya çalışma, ev sorunlarının derse yansiması, öğretmen mahremiyetine önem verilmemesi ve velinin birden çok rol alması şekline sıralamaktadırlar. Konuyla ilgili öğretmen söylemleri aşağıda sunulmuştur.

Kod 1: Derse katılmaya çalışma

Kod 2: Ev sorunlarinın derse yansimasi

Bazı velilerin öğrencilerle birlikte derse katıldığı, söz alı konuştuğu durumlarla da karşılaştım. (Ö2)

Çok fazla kamera açılmasa da açıldığında görüntüleri ve mikrofon açık olduğunda sesleri geliyor. Ders sirasinda bu sesleri duyarak evdeki bazı minik sorunlara da şahit olduğumuz oluyor. (Ö8)

\section{Kod 3: Öğretmen mahremiyetine önem vermeme}

Biz dersi işlerken öğrenciye kamera açtırmıyoruz. Biz öğretmenler kameralarımızı açıyoruz. Veli bizi her türlü görmüş oluyor. (Ö9)

Kod 4: Velinin birden çok rolü olması

Veli olarak, evde yeni bir düzen, belki eşinin evde olması, herkesin bir çalışma alanına sahip olması gerekmesi problem oluşturdu. (Ö1)

Alt Tema 2: Velilerin öğretmenlere belirlediği roller. Diğer yandan sosyal bilgiler öğretmenleri velilerin öğretmenlere yanlış rol belirlemeleri sorununu belirtmişler. Bu yanlış rolleri; internet sorununu çözen, asılsı haberlere cevap vermesi beklenen, ilgili programı kullanımını gösteren ve mesai dışında da ulaşılması beklenen şeklinde ifade etmişlerdir. İlgili örnekler şunlardır.

Kod 1: İnternet sorunlarını WhatsApp da iletişim problemleri yaşıyoruz. Internet problemi çözen olan velilerde bizi suçluyor. (Ö15)

Kod 2: Asılsız haberlere Velilerin çevreden, haberlerden duydukları Milli Eğitim tablet cevap vermesi beklenen dă̆ıtacakmış, internet dă̆ıtacakmış haberlerinden dolayı sürekli bizden destek istediler. (Ö4)

Kod 3: İlgili programı Velilerin de bu programlara yabancı olması nedeniyle onlarda kullanımını gösteren problem yaşadı. Bu programların kurulum sürecinde velilerle sık sık iletişim kurduk. (Ö2)

Kod 4: Mesai dışında da Anlamadıkları bir şey olduğunda sık arama oldu ve bu aramaların ulaşılması beklenen bazıları da olur olmaz saatlerde gerçekleşti. (Ö1)

Alt Tema 3: İlgisiz davranma/İlgilenememe. Öğretmenler velilerin ilgisizliği ile ilgili problemlerde; öğrencilerin katılımın sağlayamama, öğrenciyi süreç içinde takip etmeme ve ders saatlerinde evde ol(a)mama konularına odaklanmışlardır. Bu durum ile ilgili örnekler, öğretmenler tarafından aşağıdaki şekilde ifade edilmiştir.

Kod 1: Öğrenci Bazı velilerimizin biraz olayın üstüne düşmemesi çocukların derse katılımını sağlayamama katılımı ya da devamı konusunda sorunlar yaratıyor. (Ö5) 
Bu açıdan beni yormalarım tercih ederdim. Haftalar sonra ders programın soran velilerimiz oluyordu. (Ö1)

Kod 3: Ders saatlerinde Veli evde olmayınca çocuklar canlı derse katılmayabiliyorlar. (Ö1) evde ol(a)mama

Ders saatlerinde evde olamadığı için derslerin takibini yapamayan velilerle ilgili olarak Ö1, "Whatsapp grubu aracılı̆̆ ile canlı derse katılmayanlar velilere bildirildi." söylemi ile bu sorunu çözüme kavuşturduğunu ifade etmiştir.

Alt Tema 4: Uzaktan eğitim süreciyle ilgili inançlar. Öğretmenler, velileri uzaktan eğitimle ilgili inançlarını; süreci tatil olarak görmeleri ve velilerin uygulama sürecine aşina olmamaları şeklinde belirtmişlerdir. Bu problemlere yönelik öğretmen söylemlerinin örnekleri aşağıda sunulmuştur.

Kod 1: Süreci tatil olarak Onlar da süreci tatil olarak görüyorlar, evde çocuklarn ile uğraşmak görmeleri bazı velilerimize zor geliyor. (Ö7)

Kod 2: Uygulama sürecine Velilerin de uygulamalara yabancı olmasının sıkıntısını yaşadı. aşina olmamaları

Araştırmaya katılan sosyal bilgiler öğretmenlerinden bazıları velilerin süreç içinde kendilerine destek olduğunu belirtmişlerdir. Konuyla ilgili Ö6 "Tabi süreç içinde en büyük destekçimiz veliler oldu." şeklinde bir söylemde bulunmuştur. Öte yandan velilerin uzaktan eğitim sürecinde rollerinin çok önemli olduğunu belirten öğretmenler de bulunmaktadır. Örneğin konuya yönelik Ö11 "Şunu da belirteyim ki veliler uzaktan eğitimin temel taşıdır. Bu anlamda velilere uzaktan eğitimin önemi kavratılmalıdır." şeklinde bir ifade kullanmıştır.

\section{Tema 3: Okul yönetimi ile ilgili problemler}

Sosyal bilgiler öğretmenlerinin çoğunluğu (13/15) uzaktan eğitim sürecinde okul yönetimi ile ilgili sorun yaşamadıklarını ifade etmişlerdir. Aksine okul yöneticilerinin ellerinden gelen çabayı göstererek sürecin, öğrenciler ve öğretmenler açısından en az sorunla geçmesi için gerekli çalışmaları yaptıklarını belirtmişlerdir. Konu ile ilgili olarak Ö5 “Okul idaremiz uzaktan eğitim sürecinde gerek planlama gerekse teknik imkanlar iyileştirme konusunda bizlere ve öğrencilerimize çok yardımcı oldular." ifadesi ile süreç içerisinde okul idaresinden aldığ 1 desteği ifade etmiştir. Yine bu konuda Ö10 "Kesinlikle ve kesinlikle yaşamadık. Bu süreçte ben kesinlikle söyleyebilirim ki okul idarecileri o kadar özverili çalıştılar ki hem öğretmene hem öğrencilere ellerinden gelen kolaylı̆̆ı sağlamaya çalıştı diyebilirim." ifadesiyle okul idaresinin sürecin yönetilmesinde oldukça özverili çalıştığını belirtmiştir. Buna karşın bazı teknik sorunlar yaşandığını beyan eden katılımcılar da olmuştur. Katılımcılar okul yönetimi ile ilgili problemler teması altında yaşadıkları problemleri; "programların hazırlanması, kullanılan onkine programların tanıtılmaması, öğretmenlerin derse gireceği sinıfların paylaşılması, hafta sonu günlerine ders konulması" alt tenalarında belirtmişlerdir. Konu ile ilgili detaylar görüşleri Şekil 3'te gösterilmektedir. 
Şekil 3. Öğretmenlerin uzaktan eğitim sürecinde okul yönetiminden kaynakl yaşadıkları problemler



Alt Tema 1: Programların hazırlanması. Bu konuda Ö6, "Ders programları konusunda problemler oldu" söyleminde bulunarak öğretmenlerin uygulayacağı ders programları konusunda sorun yaşadığını belirtmiştir. Bu konuyla ilgili ayrıntılı bilgi veren Ö1 ise, "Ebada her sınıf seviyesine ders tanımlamak için verilen zaman sınırl olması nedeniyle öğrencilerin alması gereken derslerin tamamı Eba sistemine tanımlanamadı." demiştir. Ebanın canlı dersler konusunda zaman açısından oluşturduğu bu problemi çözmek için Ö1, "Eba yerine Teams, zoom gibi programlar kullanıldığııı" belirtmiştir.

Alt Tema 2: Kullanılan online programlan tanıtılmaması. Ö2 ise, "Kullandığım programlar konusunda hiç bilgilendirilmediğim için sıkıntılar yaşadık" diyerek canlı dersler sirasında kullanılan online programların kullanımı konusunda herhangi bir tanitım ya da bilgilendirme yapılmadığını ifade etmiştir. Konu ile ilgili Ö9 da "Tabii ki o dönemde zoom programı ile daha yeni tanışıyorduk daha yeni adapte oluyorduk." şeklinde yaşadığı sorunu dile getirmiştir. Öte yandan Ö9 yaşadığı sorunu çözüm olarak "bilişim öğretmenlerinden yardım aldıklarını" belirtmiştir.

Alt Tema 3: Öğretmenlerin derse gireceği sınıfların paylaşılması. Araştırmaya katılan sosyal bilgiler öğretmenleri özellikle bu süreçte uzaktan eğitim ve yüz yüze eğitimin birlikte olduğu dönemlerde derslerin paylaşılması konusunda problemler yaşandığını ifade etmişlerdir. Konu ile ilgili olarak Ö1" Öğretmenler arasında yüz yüze eğitime kim girecek bu sınıflara kim girecek böyle sorunlar yaşandı." ifadesi ile yaşadığ sorunu dile getirmiştir.

Alt Tema 4: Hafta sonu günlerine ders konulması. Uzaktan eğitim sürecinin başlaması ile derslerin planlanmasında da problemler yaşandığını belirten sosyal bilgiler öğretmenleri özellikle uzaktan eğitim sürecinin başlangıcında EBA'da canlı ders saatlerinin sınırlı olmasından kaynaklı ders yoğunluğu nedeniyle hafta sonları da ders yapmak zorunda olduklarını belirtmişlerdir. Bu konuda Ö11 "Derslerin yoğun olması ve cumartesi gününe ders koyulması biraz bizi zorladı." demiştir.

\section{Tema 4: Öğretim süreciyle ile ilgili sorunlar}

Sosyal bilgiler öğretmenleri, öğretim süreciyle ilgili sorunlar teması altında yaşadıkları sorunları; "sınava hazırlanan öğrenciler için yetersiz kalınması, farklı yöntem ve tekniklerin 
uygulanamaması, bilgilerin kahıcılı̆̆ının olmaması, müfredatın yetişmesi/ ders süresi, derslerin veriminin ve motivasyonun düşmesi, başlangıçta veli ve öğrenciyle iletişim kuramama, ödevlerin verilmesi ile yüz yüze ve uzaktan eğitimin birlikte yürütülmesi" alt temalarında ifade etmişlerdir. Konu ile ilgili bilgiler Şekil 4'te gösterilmiştir.

Şekil 4. Öğretmenlerin uzaktan eğitim sürecinde öğretim sürecinden kaynakl yaşadıkları problemler

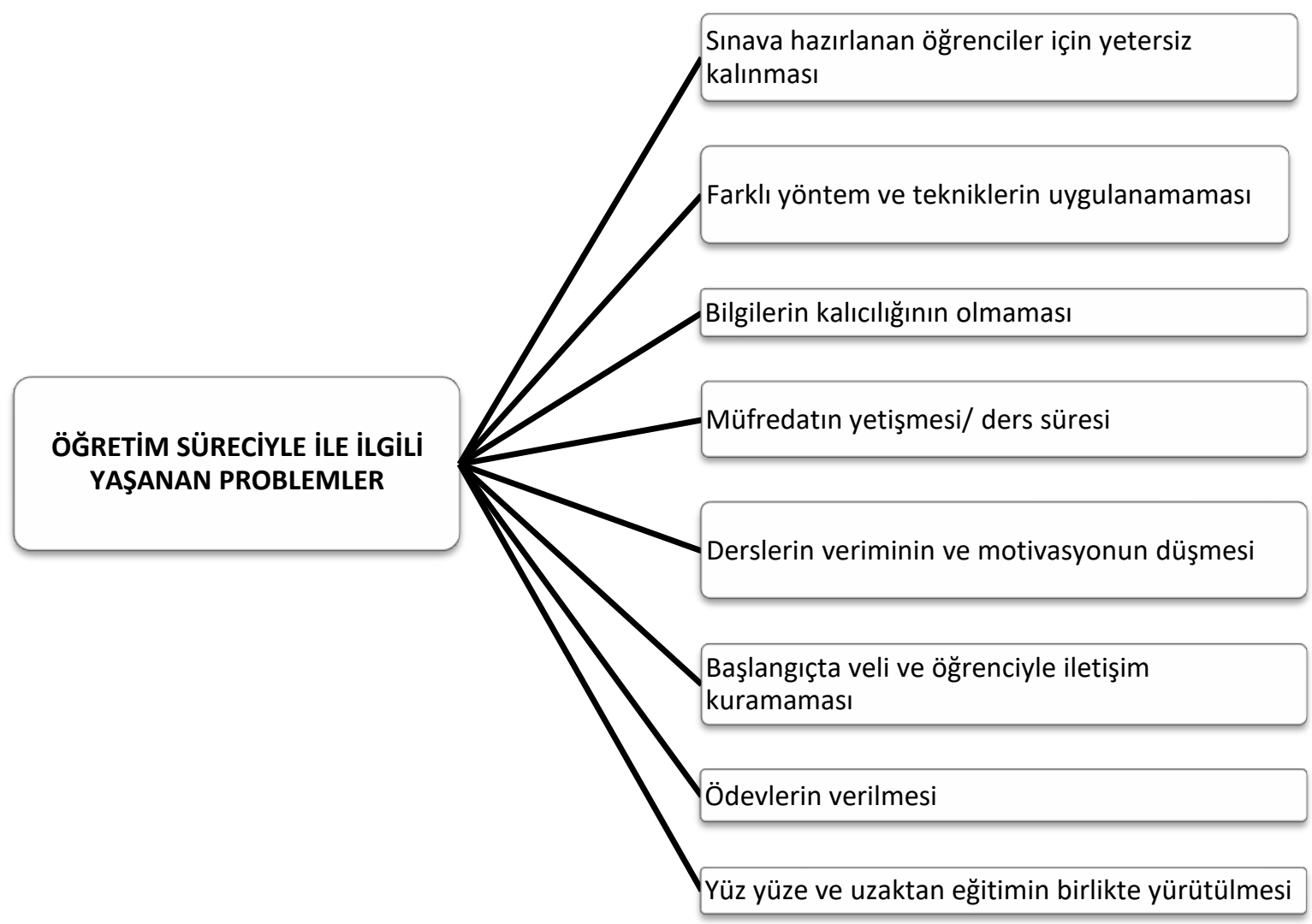

Alt Tema 1: Sınava hazırlanan öğrenciler için yetersiz kalınması. Bu konuda Ö1, "8. Sınıflar sınava gireceği için ayn müfredatın uygulanması konusunda bazı tereddütlerim var" diyerek uzaktan eğitim sürecinin sınava hazırlamada yetersiz olduğu konusundaki düşüncesini dile ifade etmiştir.

Alt Tema 2: Farklı yöntem ve tekniklerin uygulanamaması. Sosyal bilgiler öğretmenlerinden Ö4 de canlı derslerde farklı yöntem ve tekniklerin uygulanamaması konusunda "Bazı yöntem ve etkinlikleri canlı ders strasında uygulayamıyoruz" söyleminde bulunmuştur. Yine bu konuda Ö7 "Ayrıca sosyal bilgiler dersinde bazı konuların uzaktan eğitimde işlenmesi zor. Mesela 5. sinflarda yeryüzü şekillerini konusunu işlerken ben yüz yüze eğitimde çocuklardan oyun hamurları istiyordum. Sinıf içerisinde oyun hamurlarından yeryüzü şekillerini yaparak öğreniyorduk. Uzaktan eğitimde böyle bir şansımız yok. Sadece ekrana görselleri yansıtarak konuyu bu şekilde anlatma yoluna gittik yani uygulama yapamadık." diyerek bu konudaki görüşünü dile getirmiştir. 
Alt Tema 3: Bilgilerin kalıcılı̆̆ının olmaması. Ö2, "Tarih gibi yazı yazmayı, not almayı gerektiren yoruma dayalı değil de bilgi gerektiren konularda kalıcllğın zor olduğunu düşünüyorum." diyerek bilgilerin kalıcılığının olmaması konusundaki görüşünü belirtmiştir.

Alt Tema 4: Müfredatın yetişmesi/ ders süresi. Bu konuda Ö6 ise, "Ders süresinin 30 dakikaya düşmesi, konuların ayn kalması bir sorun oldu" diyerek ders süresinin müfredatın yetişmesi için yetersiz olduğu konusundaki görüşünü belirtmiştir. Diğer taraftan sosyal bilgiler öğretmenlerinin bir bölümü de uzaktan eğitim sürecinde derse başlarken her hangi bir hazırlık ve toparlanma süreci gerektirmediği için uygulanan 30 dakikalık ders süresinin yeterli olduğunu belirtmişlerdir. Bu konuda Ö1, "Derslerin 30 dakika olmasıyla ilgili ayrı bir planlama yapmıyorum. Zaten normal zamandaki 40 dakikayla eşdeğer bir ders işleme süresi yaşıyoruz burada." söyleminde bulunarak bu konudaki görüşünü ifade etmiştir.

Alt Tema 5: Derslerin verimi ve motivasyon düşüklüğ̈̈. Öğretmenler uzaktan eğitim sürecinde ev ortamında yapılan online derslerin dersin verimini ve öğretmenin motivasyonunu da etkilediğini belirtmişlerdir. Sosyal bilgiler öğretmenleri ev ortamında yapılan derslerde zil çalması, dışarıdan gelebilecek sesler ve ev içerisinden kaynaklı gürültüler gibi nedenlerle dersin akışının bozulduğunu ve bu durumun da dersin verimini ve öğretmenin motivasyonunu düşürdüğünü ifade etmişlerdir. Örneğin Ö2 "Ders işleyişimi bölen şeyler oluyor. Kapı çalıyor mesela ve o kapıyı açmam gerekiyor. Ders aralarında zamanın girmesi dikkatimizi dağıtan daha çok şey oluyor. Bu da bir sonraki derse daha verimsiz girmemize neden oluyor." diyerek konu ile ilgili düşüncesini ifade etmiştir. Ayrıca araştırmaya katılan öğretmenler uzaktan eğitim sürecinin ev ortamında okuldaki ciddiyetinin dışına çıktığını ve ev ortamında yapılan dersin öğretmende günlük rutin ev işlerini yapıyormuş hissi oluşturduğunu ifade etmişlerdir. Konu ile ilgili olarak Ö2 "Okuldaki gibi bir çalışma ortamı yaratamıyorum. Bu da sanki asli görevimi değil de ev işlerimi daha çok yapıyorum gibi hissettiriyor." demiştir.

Alt Tema 6: Başlangıçta veli ve öğrenciyle iletişim kuramama. Sosyal bilgiler öğretmenleri pandemi nedeniyle yüz yüze eğitime ara verilmesi ile başlayan uzaktan eğitim sürecinin başlangıcında veli ve öğrencilerle iletişim kurma konusunda zorlandıklarını belirtmişlerdir. Konu ile ilgili olarak Ö1 "veli ve öğrenci ile iletişim să̆lanamadı̆̆ı" yönünde yaşadığ1 sorunu dile getirmiştir. Bu konu ile ilgili yaşadığ1 soruna çözüm olarak Ö1 "Whatsapp grupları kuruldu. Sürekli irtibat să̆landı." şeklinde görüş belirtmiştir.

Alt Tema 7: Ödevlerin verilmesi. Uzaktan eğitim sürecinde yaşanan sorunlardan bir tanesinin de öğrencilere ödevlendirmelerin yapılması olduğunu vurgulayan Ö1, bu konuda yaşadığı sorunu "Yine ödevleri Whatsapp grubundan göndererek daha kolay iletişim kurabiliyorum." ifadesi ile çözüme kavuşturduğunu ifade etmiştir.

Alt Tema 8: Yüz yüze ve uzaktan eğitimin birlikte yürütülmesi. Salgının Türkiye'deki seyrine göre dönem dönem alınana kararlar doğrultusunda 5. ve 8. sinıflarda okullarda yüz yüze eğitim başlamış olup bu süreçte öğrenciler hem uzaktan eğitim hem de okulda yüz yüze eğitim almışlardır. Araştırmaya katılan öğretmenler bu durumun derslerin işlenişinde problemler ortaya çıkardığını belirtmişlerdir. Konu ile ilgili olarak Ö5 "8. sımıflarda yüz yüze eğitim başladı̆̆ında uzaktan eğitim derslerine hiç katılmayan öğrenciler canlı derslere katıldı." diyerek 8. sınıfların yüz yüze eğitime başlaması ile uzaktan eğitime katılan ve katılamayan öğrenciler arasında oluşan seviye farklarına dikkati çekmiştir. Bu sorunu çözmek için Ö5 "Ama kazanımı yetişmek zorunda olduğumdan konuyu devam ettirdim. Gelmeyenler için kısa özetler yaptım." 
demiştir. Yine Ö15 "8. sinıflarda canlı derslerde beraber yürütmeye çalıştım. Daha sonra yüz yüze eğitime gelmeyen çocuklar olduğu için yüz yüze ve canlı dersleri ayrn yönettim." diyerek konu ile ilgili bulduğu çözümü ifade etmiştir.

\section{Tema 5: Ev/yaşam ve aile düzeni ile ilgili problemler}

Pandemi sürecinde uzaktan eğitimin günlük yaşantılarını ve aile hayatlarını etkilediğini belirten öğretmenler bu etkiyi; "ebeveyn rolü, eş (öğretmen ise), evin düzeni ve kendisi" alt temaları altında ifade etmişlerdir. Alt temalar kendi içlerinde kodlara ayrılmaktadır. Şekil $5^{\prime}$ te ev/yaşam ve aile düzeniyle ilgili yaşanılan problemler özetlenmiştir.

Şekil 5. Öğretmenlerin uzaktan eğitim sürecinde ev/yaşam ve aile düzeni ile ilgili yaşadıkları problemler

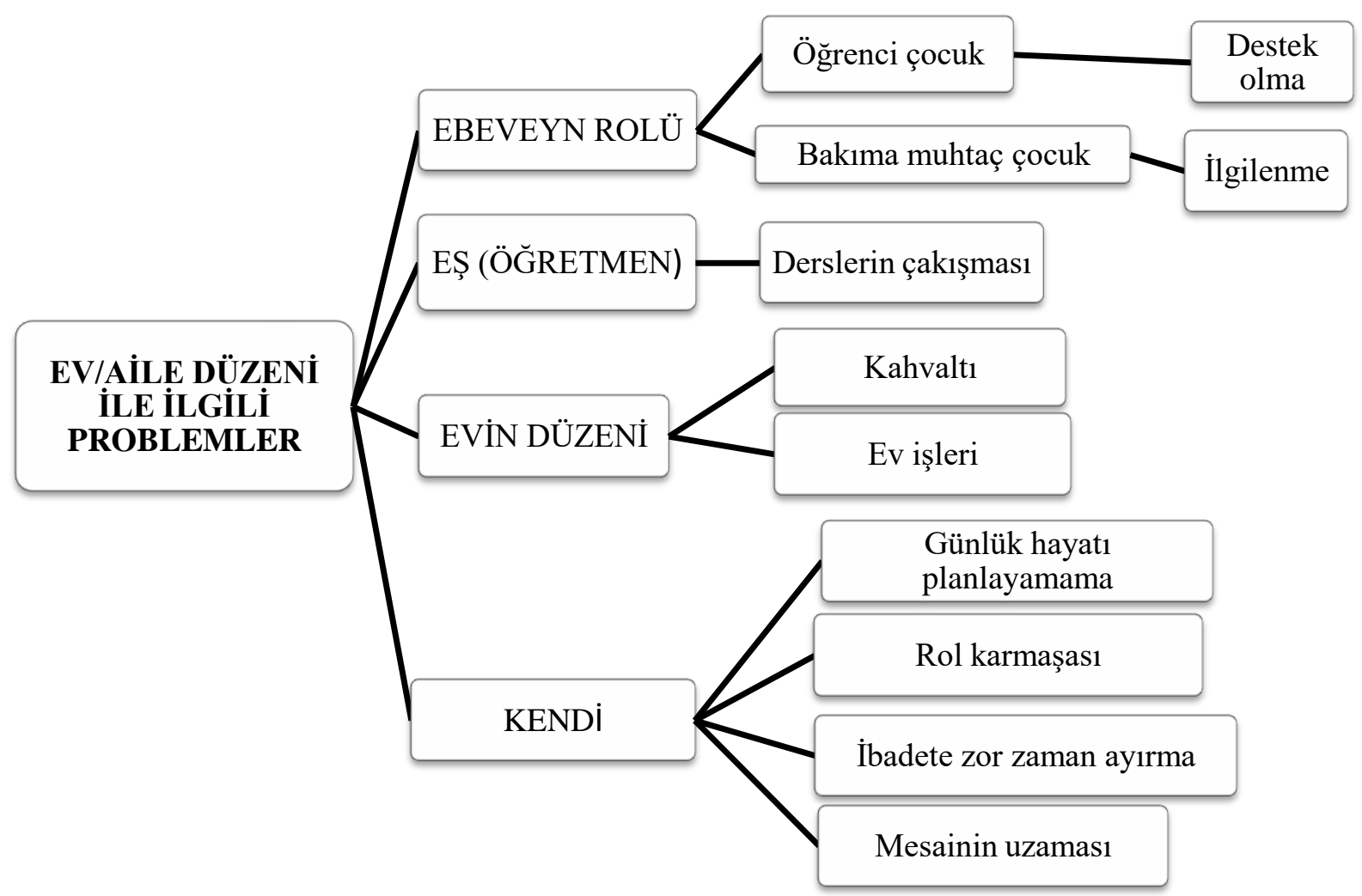

Alt Tema 1: Ebeveyn Rolü ile ilgili sorunlar. Uzaktan eğitim sürecinin günlük hayatlarını ve aile hayatlarını etkilediğini belirten sosyal bilgiler öğretmenleri ebeveyn rolü ile ilgili sorunlarını ögrrenci çocuk ve bakıma muhtaç çocuk başlıkları altında ifade etmişlerdir.

Kod 1: Öğrenci çocuk. Bu konu bağlamda öğretmenlerin bir bölümü okula giden öğrencilerinin de uzaktan eğitim sürecine dahil olduğunu ve kendi derslerinin yanında çocuklarının da derse bağlanmaları konusunda çocuklarına destek vermeleri gerektiğini ve bu hususta zorluklar yaşadıklarını ifade etmişlerdir. Örneğin Ö6 "İlk başta EBA'nın canlı derslerde açılması oldukça zor olduğu için kendi dersimi bitirip oradan çocuğumun dersini açmak için koşup uğraşıyorduk." diyerek konu ile ilgili görüşünü dile getirmiştir. 
Kod 2: Bakıma muhtaç çocuk. Araştırmaya katılan öğretmenlerden bir kısmı ise pandemi sürecinde online eğitim sırasında okula gitmeyen küçük yaştaki çocuklarının kendilerinden ilgi beklediklerini fakat ders esnasında çocukları ile ilgilenmelerinin mümkün olmaması nedeniyle zorluklar yaşadıklarını dile getirmişlerdir. Bu konuda Ö1 "Küçük bir çocuğum var benim. En çok o etkilendi sanırım. Ders sırasında ona oyalanabileceği etkinlikler vermeye çalışıyorum." demiştir.

Alt Tema 2: Eş (Öğretmen) ile ilgili sorunlar. Diğer yandan araştırmaya katılan öğretmen olan eşler derslerinin çakışması nedeniyle uzaktan eğitim sürecinde zorluklar yaşadıklarını ifade etmişlerdir. Bu hususta Ö5 “Eşimin de öğretmen olması sebebiyle ikimizin de derste olduğu sıralarda küçük çocuğumuzun yalnız kalması bizi zor durumda bırakıyor. Bu süreçte bakıcı ya da kreş gibi seçeneklere de yönelemememiz günlük hayatımızın biraz koşturma ve stresli bir hal almasına neden olduğunu söyleyebilirim." ifadesi ile konu ile ilgili düşüncesini dile getirmiştir. Buna ilave olarak eşi de öğretmen olanların, uzaktan eğitim derslerinin çakışması nedeniyle araç gereç konusunda sorun yaşadıkları ifade edilmiştir. Konu ile ilgili olarak Ö9 "illk dönemlerde evde internet ve teknolojik araç sıkıntısı yaşadım. Kendi bilgisayarım vardı fakat bilgisayarımı hem çocuğum öğrenci olarak kullanıyordu, hem de eşim öğretmen olarak kullanıyordu. Bu nedenle ben canl derslerimi ilk etapta okulda gerçekleştirmeye başladım. Şu an eşim evdeki bilgisayarı kullanıyor, çocuğum telefon ile canlı derse katılıyor, ben ise komşumun kullanmadığı bilgisayarını ödünç aldım, onunla canlı derslerimi gerçekleştiriyorum." diyerek yaşadığı güçlügüu dile getirmiştir.

Alt Tema 3: Evin Düzeni ile ilgili sorunlar. Uzaktan eğitim sürecinde öğretmenlerin online derslerini ev ortamında gerçekleştirmesi nedeniyle evin düzeninin de bu durumdan etkilendiği araştırmaya katılan sosyal bilgiler öğretmenleri tarafından belirtilmiştir. Sosyal bilgiler öğretmenleri ev düzeni teması altında uzaktan eğitim sürecinin günlük yaşantılarını ve aile hayatlarını etkilemesini kahvaltı ve ev işleri başlıkları altında ifade etmişlerdir.

Kod 1: Kahvaltı. Uzaktan eğitim sürecinin başlaması itibariyle evde kahvaltı saatleri konusunda farklılıklar yaşandığı, tüm ailenin aynı anda kahvaltı masasına oturamadığ $\breve{g}_{1}$ belirtilmiştir. Konu ile ilgili olarak Ö 8 "Şöyle düşünürsek bütün aile evde, evde de uzaktan eğitim alan 3 tane öğrenci kendi ailem için konuşuyorum. Kendimle beraber 4 kişi aynı anda bu sürece katıliyor. Dolayısıyla bir karmaşa oluşuyor ister istemez. Örneğin kahvaltı masasında herkesi aynı anda toplamak mümkün olmuyor." diyerek düşüncesini ifade etmiştir.

Kod 2: Ev işleri. Yine araştırmaya katılan sosyal bilgiler öğretmenleri evde ders esnasında gürültü çıkaracağı gerekçesiyle bazı ev işlerinin de ders saatlerine göre düzenlendiğini bu durumun da evin günlük rutin düzenini değiştirdiğini vurgulamıştır. Bu hususta Ö8 “Örnek vermek gerekirse bir elektrik süpürgesi açılacak açılmıyor. Temizlik günü değişiyor evde, hafta içi yapılırken hafta sonuna kaydırılıyor. Çünkü herkes evin bir köşesinde derse katılmaya çalışıyor. Bu gibi durumlar evde yaşanabiliyor. Yani evin iç düzeni ister istemez bu uzaktan eğitim sürecine uyarlanıyor." diyerek bu konudaki görüşünü dile getirmiştir.

Alt Tema 4: Kendi ile ilgili sorunlar. Araştırmaya katılan sosyal bilgiler öğretmenleri uzaktan eğitim sürecinin günlük yaşantıları ve aile hayatları ile birlikte kendilerini de bireysel anlamda etkilediğini belirtmişlerdir. Bu bağlamda öğretmenler "kendi" teması altında bu etkiyi; günlük hayatı planlayamama, rol karmaşası, ibadete zaman ayıramama ve mesainin uzaması başlıklarında değerlendirmişlerdir. 
Kod 1: Günlük hayatı planlayamama. Uzaktan eğitim sürecinde derslerin online olarak yapılması ve planlanan derslerin gün içerisinde yayılma göstermesi nedeniyle öğretmenler günlük hayatlarını planlamakta zorlandıklarını ifade etmişlerdir. Konu ile ilgili olarak Ö 15 "Dersler çok geç bitiyor. Arada boş dersler olması kötü oluyor. Bazen kahvaltı yapamadığım oldu. Eşimle dersler çakışıyor. Birbirimizin sesini ders esnasında duymamaya çalışıyoruz. Kızımı kreşe kim götürecek? Bu problem oluyor. Kendi yaşantımızı planlayamıyoruz." diyerek düşüncesini dile getirmiştir.

Kod 2: Rol karmaşası. Öte yandan öğretmenler uzaktan eğitim sürecinde ev ortamında olmaları nedeniyle ev içerisinde sahip oldukları anne veya baba rolleri ile öğretmen rolleri arasında anlık değişimler yaşamak zorunda olduklarını ifade ederek yaşadıkları rol karmaşasını dile getirmişlerdir. Örneğin Ö7 "Evden çalışma hayatın yürütmek bir kere başlı başına zor bir durum. Özellikle kadınlar için zor bir durum. Çünkü hem evde annesiniz bir de evde iş yapıyorsunuz, öğretmensiniz, canlı dersleriniz oluyor. Dolayısıyla hepsini bir arada yürütmek zor." diyerek yaşadığ1 rol karmaşasını ifade etmiştir.

Kod 3: İbadete zaman ayıramama. Derslerin tüm güne yayılması, dersler arasındaki teneffüs süresinin az olması ve diğer derse hazırlık için geçirilen zaman da göz önüne alındığında öğretmenler ibadete zaman ayırmada zorlandıklarını belirtmişlerdir. Bu konuda Ö9 “Örneğin namaz ibadetini yapmaya dahi vakit bulmakta zorlanıyorduk. Teneffüsün birinde sünnet namazın kılarken diğer teneffüste farz namazını kılıyorduk." diyerek yaşadığı güçlügü dile getirmiştir.

Kod 4: Mesainin uzaması. Araştırmaya katılan öğretmenler uzaktan eğitim sürecinde öğrenci ve velilerin süreç ile ilgili birçok bilinmeyen soru ile karşılaştıklarını ve bu bilinmezlikleri gidermek adına sürekli öğretmenler ile iletişim kurduklarını belirtmiş olup bu iletişimin bazı zamanlarda geç saatlere kadar devam ettiğini ve bu durumun mesai kavramının ortadan kalkmasına neden olduğunu belirtmişlerdir. Örneğin Ö5 "Bu süreçte öğrencilerle daha sık iletişimde kalmak zorunda olmamız gün içinde saat kavramı olmaksızın mesaide kalmamıza neden olduğunu söyleyebilirim." diyerek konu ile ilgili düşüncesini ifade etmiştir.

Diğer yandan araştırmaya katılan öğretmenlerden bazıları uzaktan eğitim sürecinin günlük yaşantılarını ve aile hayatlarını etkilemediğini belirtmiştir. Bu konuyu öğretmenler zaman ve mekan bağlamlarında ele almışlardır. Araştırmaya katılan öğretmenler pandemi öncesinde okullarda eğitim faaliyetlerini yürütürken derslerin başlangıç ve bitiş saatleri olduğunu, uzaktan eğitim sürecinde evde gerçekleştirilen online derslerin de başlangıç ve bitiş saatleri bulunduğunu belirtmiş olup bu bakımdan değerlendirildiğinde okulda yüz yüze eğitimde derslere ayrılan zamanın şimdi evde online derslere ayrılması nedeniyle bir farklılığın yaşanmadığını belirtmişlerdir. Konu ile ilgili olarak Ö8 "Şöyle düşünürsek normalde mesai olarak o süreç içerisinde ders planlarımızın olduğu ki bizim okulumuzda gayet güzel planlandiğı için ve derslerimiz hafta içi belirli saatlerde olduğu için normalde okullarda olmamız gerek zamandı dersleri yaptığımız zaman dilimi." diyerek düşüncesini dile getirmiştir. Yine araştırmaya katılan öğretmenlerden bazıları uzaktan eğitim sürecinde online derslerini okul ortamında gerçekleştirdiği için bu durumun günlük yaşantılarını ve aile hayatlarını etkilemediğini belirtmiştir. Örneğin Ö11 "Ben derslerimi okulda verdiğim için aile hayatımı etkilemiyor diyebilirim." diyerek konu ile ilgili düşüncesini dile getirmiştir. Bunun dışında araştırmaya katılan ebeveyn olan öğretmenler uzaktan eğitim sürecinde ev ortamında ders vermenin kendi çocuklarını kreşe ve bakıcıya vermemeleri sebebiyle ders aralarında çocukları ile ilgilenebilmeleri ve vakit geçirebilmeleri açısından kendileri için avantaj teşkil ettiğini de belirtmişlerdir. Konu ile ilgili 
olarak Ö 3 "Bu süreçte çocuğumuzun bakıct ile değil bizimle vakit geçirmesi bir avantaj oldu." diyerek düşüncesini ifade etmiştir.

\section{TARTIŞMA VE SONUÇ}

Bu çalışma ile sosyal bilgiler öğretmenlerinin pandemi döneminde yürüttükleri uzaktan eğitim derslerinde karşılaştıkları problemler ve bu problemlere buldukları çözüm yollarının ortaya konulması amaçlanmaktadır. Çalışma ile sosyal bilgiler öğretmenlerinin uzaktan eğitim sürecinde çeşitli problemlerle karşılaştıkları ve bu problemler ile baş etmek için farklı çözüm yolları buldukları sonucuna ulaşılmıştır. Çalışmada öğretmenlerin karşılaştıkları sorunlar öğrenci, veli, okul yönetimi ve süreç, ev yaşamı ve aile düzeni ile ilgili de problemler temaları altında belirtilmiştir.

Araştırma sonucunda, öğretmenlerin uzaktan eğitim sürecinde en fazla öğrenci kaynaklı problem yaşadığı tespit edilmiştir. Pandemi döneminde uzaktan eğitim ile derslerini yürüten öğretmenlerin yaşadıkları sorunlar ile ilgili yapılan diğer çalışmalar incelendiğinde Aydemir, (2021)'in sosyal bilgiler öğretmenleriyle, Bakıŏlu (2020)'un ise fen bilimleri öğretmenleriyle yaptıkları çalışmalarda öğretmenlerin en çok öğrenciler ile ilgili problemler yaşadıkları sonucuna ulaştığı görülmüştür. Bu çalışmanın sonucunda sosyal bilgiler öğretmenlerinin öğrenci ile ilgili yaşadıkları problemler; öğrencilerin derse katılmaması/katılamaması, disiplinsizlik, motivasyon düşüklüğü, iletişim kuramama ve ortam ile fiziki ortamın uygun olamaması alt temalarına ulaşılmıştır. Öğrencilerin derse katılmama/katılamaması alt teması öğretmenlerin birçoğunun uzaktan eğitimde yaşadığı problem olarak öne çıkmaktadır. Öğretmenler bu problemin sebebi olarak, öğrencilerin teknik donanım eksiklĭgi yaşamalarını, internetlerinin olmamasını, evde birden fazla kardeşin canlı derslere katılmasını ve bağlantı sorunları yaşamaların göstermişlerdir. Araştırmada elde edilen bulgulara göre özellikle öğrencilerin teknik donanıma sahip olmamaları ve internet problemleri yaşamaları derslere katılım oranlarını büyük ölçüde düşürmektedir. Avcı ve Akdeniz (2021), Oyedotun (2020), Balaman ve Tiryaki (2021), Morgan (2020) da yaptıkları çalışmalarda uzaktan eğitime katılamayan öğrencilerin birçoğunun teknik donanım eksikliği yaşadıkları sonucuna ulaşmışlardır. Kaya (2002)'ya göre de uzaktan eğitimin, ulaşım imkanlarına ve teknik yeterliliklere bağlı olması, pandemi sürecinde kurulan sistemin sinırlılıkları arasındadır. Saygı (2021) ile Alea, Fabrea, Roldan ve Farooqi, (2020) ise yaptıkları çalışmalarda özellikle kırsal kesimde yaşayan öğrencilerin teknik donanım eksikliği problemini daha fazla yaşadıkları sonucuna ulaşmışlardır. Araştırmada ulaşılan sonuç bu anlamda literatürde yapılan diğer araştırmalarla da örtüşmektedir. Öğrencilerin derse katılmaması/katılamaması alt teması altında bulunan diğer problem ise evde öğrenci ile birlikte canlı derslere katılması gereken başka kardeşlerinin olmasıdır. Evde uzaktan eğitim dersine katılmak için gerekli olan tek bir teknolojik cihaz bulunması aynı zaman diliminde dersi bulunan kardeşlerden birinin mağduriyet yaşamasına neden olmaktadır. Kabapınar, Kanyılmaz, Ören Koçhan ve Atik (2021) de yaptıkları çalışmada çocuk sayısının fazla olmasının bilgisayar, tablet, televizyon gibi cihazların yetersiz kalmasına neden olduğu, bu durumun da derse katılım oranını düşürdüğü sonucuna ulaşmıştır. Araştırma ile ulaşılan sonuç literatür ile de örtüşmektedir. Öğrencilerin derse katıldığı halde ders işleme sürecine aktif olarak katılamaması derse katılmama/katılamama teması altında ulaşılan diğer bir sorundur. Katılımcılar tarafından yaşanan sorunun sebebi olarak, öğrencinin mikrofonunun olmaması ya da öğrencinin derse katılmamak için bahaneler öne sürmesi olarak gösterilmiştir. 
Araştırmada öğretmenlerin uzaktan eğitim sürecinde öğrenciler ile yaşadıkları problemler başlığı altında ulaşılan diğer alt tema da disiplinsiz temasıdır. Disiplinsizlik alt teması altında yaşanılan sorunlara genel açıdan bakıldığında canlı ders yapılırken öğrenci kontrolünün tam olarak sağlanamamasının istenmeyen durumların yaşanmasına neden olduğu görülmüştür. $\mathrm{Bu}$ bağlamda özellikle uzaktan eğitimde kullanılan çevrimiçi uygulamaların farklı özelliklerinin olmasının (isim değiştirme, farklı sınıfların dersine bağlanabilme) bu sorunlara neden olduğu katılımcılar tarafından belirtiilmiştir. Katılımcılar disiplinsizlik alt teması altında öğrencilerin ders sırasında başka işle meşgul olduklarını, dersi sabote etme girişimlerinde bulunduklarını, ders esnasında gereksiz yazışmalarda bulunduklarını, derse geç girip erken çıkıklarını, ödevlere özen göstermediklerini, dersi dinlemediklerini belirtmişlerdir. Araştırma sonucunda katılımciların uzaktan eğitim sürecinde ödev verme ve takibi konusunda ciddi problemler yaşadıkları ortaya konulmuştur. Öğrencileri konuya hazırlamak, öğrenmeyi kolaylaştırmak ve konuyu pekiştirmek amaciyla kullanılan ödevler eğitimde öğrenciye sorumluluk kazandırmanın bir aracı olarak da kullanılmaktadır (Güneş, 2014). Öğrenci katılımının ve geri dönütlerin çok kısıtlı yaşandığı uzaktan eğitim sisteminde ise ödev verme ve takibini yapma konusu oldukça zor bir durum olmaktadır. Bu bağlamda katılımclar da ödev konusunda özelikle öğrencilerin ödevlere karşı ilgisiz olduğunu belirtmişlerdir. Oyedotun (2021), Balaman ve Tiryaki (2021) de yaptıkları çalışmalarda, araştırma sonucu ile benzer şekilde uzaktan eğitim sürecinde öğretmenlerin ödev ve geri dönüt konusunda problem yaşadığı sonucuna ulaşmışlardır.

Araştırma sonucu öğrenciler ile yaşanılan probler başlığı altında yaşanan sorunlardan biri de motivasyon düşüklüğü alt teması olarak belirlenmiştir. Akgül ve Oran, (2020); Avc1 ve Akdeniz, (2021); Karaca, Özcan, Karaca ve Karamustafaoğlu (2021) da yaptıkları araştırmalarda uzaktan eğitim sürecinde öğretmenlerin karşılaştıkları temel problemlerden biri olarak öğrencilerin motivasyon eksikliği sonucuna ulaşmışlardır. Araştıma bu sonucu ile literatürde yapılan çalışmaların sonuçlarıyla örtüşmektedir. Araştırmaya katılan öğretmenlerin büyük bölümü öğrencilerinde motivasyon eksikliğinin temel nedeni olarak öğrencinin ilgisiz olmasını, eğitim sürecinin ciddiyetten uzaklaşmasını ve öğrencilerin ders sürecinden kopmasını belirtmişlerdir. Oysa ki eğitim öğretim faaliyetlerinin başarıya ulaşmasında gerekli şartlardan birisi olan motivasyon, öğrencinin bir amaca ulaşmak için sahip olduğu eğilimdir. Ve bu eğilim sonucunda başarıyı elde eden öğrenci yeni başarılar için de büyük istek duyacaktır (Akbaba, 2010). Eğitimde motivasyon, verimli öğrenmenin gerçekleştirilmesi, kişinin öğrenme sürecine adanmışlığının sağlanması ve öğrenme sürecinin sağlıklı bir şekilde devamının sağlanması olarak da ifade edilebilir. Bu bağlamda öğrencide motivasyon düşük olduğunda öğrenmenin de düşük olacağı ifade edilebilir (Sezgin, 2021). Yapılan bu açıklama da desteklemektedir ki uzaktan eğitimde öğrencide motivasyonun düşük olması veya zamanla düşmesi derslerin işlenişindeki verimi ve bu bağlamda öğrenme düzeyinin de azalması sonucunu ortaya çıarmaktadır.

Araştırmada öğretmenlerin öğrencilerle yaşadıkları ulaşılan bir diğer problem iletişim kuramama alt teması altında belirtilmiştir. İletişim teması altında öğretmenlerin yaşadıkları problemlerden biri ders esnasında sorulan sorulara öğrenciden cevap alınamaması olarak belirtilmiştir. Öğretmenler ders esnasında sordukları sorulara öğrencilerden cevap alamadıklarını, teknik aksaklıklar ve öğrencilerin isteksiz olmaları nedenleriyle sorulara cevap vermediklerini belirtmişlerdir. Bu durum da uzaktan eğitimin yarattığı ve ders işleme sürecini olumsuz etkileyen önemli bir problem olarak ortaya çıkmaktadır. Araştırmaya katılan 
öğretmenler, özellikle sosyal bilgiler dersinde iletişimin çok önemli olduğunu, ders işleme sürecinin öğrencilerden gelen geri dönütlerle şekillendiğini belirtmişlerdir. Aydemir (2021), Avcı ve Akdeniz (2021), Kaymaz (2021) ile Kazu, Bahçeci ve Yalçın (2021) çalışmalarında benzer sonuçlara ulaşmışlardır. Araştırma ulaşılan bu sonucu ile literatürde konu ile ilgili yapılan araştırma sonuçları ile örtüşmektedir.

Araştırma sonucunda öğretmenlerin öğrencilerle ilgili yaşadıkları diğer sorun da fiziki ortamın uygun olmaması alt teması altında belirtilmiştir. Bu konuda da özellikle ders sırasında, arka plandan gelen seslerin ve ev içerisinde aile bireyleri arasında yaşanan problemlerin derse yansıdığı belirtilmiştir. Böyle bir durumda öğrencinin mikrofonunu açmak istemediği ve dolayısıyla iletişim sorunları yaşanmasının kaçınılmaz olduğu katılımcılar tarafından belirtiilmiştir.

Çalışma sonucu ile, öğretmenlerin uzaktan eğitim sürecinde veli kaynaklı problemler yaşadıklarını ortaya koymaktadır. Veli kaynaklı yaşanan problemler teması ; "fiziki ortamın düzenlenmemesinden kaynakl sorunlar, velilerin öğretmenlere belirlediği roller, ilgisiz davranma ya da ilgilenmeme ve uzaktan eğitim süreciyle ilgili inançlar" alt temaları altında belirtilmiştir. Belirtmek gerekir ki eğitimde ve çocukların gösterecekleri akademik başarıda okul ile birlikte velilerin de oldukça önemli bir payı bulunmaktadır. Velilerin eğitim-öğretim faaliyetlerine ilgisi öğrencinin akademik başarısını arttırmaktadır (Đurišic ve Bunijevac, 2017). Pandemi ile başlayan uzaktan eğitim sürecinde ise velilerin rolü daha da önemli hale gelmiştir. Bu durum araştırmaya katılan öğretmen söylemlerine de yansımıştır. Araştırmaya katılan öğrenmenler veli ile yaşanan sorunlar başlı̆̆ı altında yaşanılan en önemli sorunun velilerin ilgisiz davranması olduğunu belirtmişlerdir. Aydemir, (2021); Avcı ve Akdeniz, (2021); Çakın ve Külekçi, (2020); Kabapınar ve diğerleri, (2021); Kurt, Kandemir ve Çelik, (2021); Şahan ve Parlar, (2021) da yaptıkları çalışmalarında araştırma ile benzer sonuçlara ulaşmışlardır.

Araştırmada ulaşılan sonuca göre katılımcılar uzaktan eğitim sürecinde okul yönetimi ile ilgili problemler yaşadıklarını belirtmişlerdir. Okul yönetimi teması altında yaşanan problemler; programların hazırlanması, kullanılan online programları tanıtılmaması, öğretmenlerin derse gireceği sımıfların paylaşılması ve hafta sonlarına ders konulması alt temaları altında belirtilmişdir. Canbolat ve Yıldırım (2021)'ın çalışmasında da benzer şekilde okul yönetimi ile ilgili problemlerin varlığına ulaşılmıştır. Bunun yanında katılımcıların önemli bir bölümü de okul yönetiminin bu süreçte elinden gelen çabayı göstererek süreci iyi yönetmek adına çaba göstediğini belirtmiştir. Bakığlu (2020) fen bilgisi öğretmenlerine yönelik çalışmasında öğretmenlerin bu süreçte en az sorunu okul yöneticileri ile yaşadıklarını tespit etmiştir. Araştırma bu sonucu ile literatürde konu ile ilgili yapılan araştırmalar ile örtüşmektedir.

Sosyal bilgiler öğretmenlerinin uzak eğitim konusunda yaşadıkları bir diğer problem ise "süreç" ten kaynaklanmaktadır. Öğretmenler süreç kaynaklı sorunlar teması altında yaşadıkları sorunları; "sınava hazırlanan öğrenciler için yetersiz kalınması, farklı yöntem ve tekniklerin uygulanamaması, bilgilerin kahıcllğııın olmaması, müfredatın yetişmesi/ ders süresi, derslerin veriminin ve motivasyonun düşmesi, başlangıçta veli ve öğrenciyle iletişim kurulamaması, ödevlerin verilmesi, yüz yüze ve uzaktan eğitimin birlikte yürütülmesi" alt temaları altında belirtilmiştir. Sosyal bilgiler öğretmenleri yüz yüze eğitimle işlenen derslerde kullanılan yöntem ve teknikleri, uzaktan eğitim yolu ile işlenen derslerde kullanamadıklarını vurgulamışladır. Benzer şekilde Bakığlu (2020), fen bilgisi öğretmenleri ile yaptığı araştırma sonucunda katılımcıların uzaktan eğitimle işledikleri derslerde düz anlatım ve soru-cevap 
yöntem ve tekniklerini kullandıklarını belirterek uzaktan eğitim sürecinin bu noktada kendilerini sınırlandırdığı sonucuna ulaşmıştır. Kavuk ve Demirtaş, (2021) ise yaptıkları araştırmada uzaktan eğitimde sıklıkla kullanılan öğretim yöntemlerinin düz anlatım ve sorucevap olduğu sonucuna ulaşmıştır. Öğrencilerin de aktif katılacağı öğretim yöntemlerini uygulamakta zorluk çektikleri ve öğretim materyalleri kullanımı konusunda zorluklar olduğunu ifade etmişlerdir. Avcı ve Akdeniz (2021) ise, okulda yüz yüze eğitimde yapılan etkinliklerin çok az kısmının uzaktan eğitim ile yapılabildiğini belirtmiştir. Yöntem, hedefe ulaşmada izlenecek olan özel yolların bütünü, teknik de bu bütünlüğü oluşturacak olan özel yollardır (Yıldızlar, 2018). Bu bağlamda kazanımlara ulaşmada önemli bir araç olan yöntem ve tekniğin uzaktan eğitim sürecinde uygulanmasında karşılaşılan zorlukların süreci zorlaştırdığ1 tespit edilmiştir. Sosyal bilgiler dersi içinde yer alan tarih konularının uzaktan eğitim sürecinde işlenmesinin ve kalıcıllğının az olduğu, öğretmenler tarafından vurgu yapılan bir diğer husustur. Öğrencilerin uzaktan eğitim sürecinde yeni bilgiler öğrenmekte ve öğrenilen bilgilerin pekiştirilememesi nedeniyle hatırlamada zorluklar yaşamaları bu durumun sebebi olarak belirtilebilir (Çakın ve Külekçi, 2020). Çalışmada ayrıca uzaktan eğitim yoluyla ev ortamında işlenen derslerde sınıf ortamının sağlıklı bir şekilde oluşturulamadı̆̆ı, ev ortamındaki uyarıcıların hem öğretmenin hem de öğrencinin dikkatini dağıttığı, bu durumun da eğitim sürecinde motivasyonu düşürdüğünü sonucuna ulaşılmıştır. Oyedotun (2020) da yaptığı çalışmada; çevrimiçi eğitimin, öğrencileri dikkat dağınıklığına neden olabilecek uyaranların çok fazla olduğu ve ev içi sorunlarla karşı karşıya kaldıkları ev ortamında ortamında derse katılmaya zorladığı için, çoğu öğrencide çevrimiçi öğretim sırasında odaklanamama veya odaklanmayı sürdürememe gibi sorunların yaşandı̆̆ı sonucuna ulaşmıştır. Bu anlamda araştırma sonucu ile literatürde yapılan araştırmalar ile benzer sonuca ulaşılmıştır. Yine bu süreçte yaşanan sorunlardan biri de öğrencilerin dikkatlerini toplama ve sürdürmeleridir. Avcı ve Akdeniz (2021) yaptıkları çalışmalarında uzaktan eğitim sürecinde yaşanan motivasyon eksikliği ve verim konusuna dikkat çekmişlerdir. Eğitimde motivasyon, verimli öğrenmenin gerçekleştirilmesi, kişinin öğrenme sürecine adanmışlığının sağlanması ve öğrenme sürecinin sağlıklı bir şekilde devamının sağlanması olarak ifade edilebilir. $\mathrm{Bu}$ bağlamda öğrencide motivasyon düşük olduğunda öğrenme de düşük olacağ1 ifade edilebilir (Sezgin, 2021). Yapılan bu açıklama da desteklemektedir ki uzaktan eğitimde öğrencide motivasyonun düşük olması veya zamanla düşmesi derslerin işlenişindeki verimi ve bu bağlamda öğrenme düzeyinin de azalması sonucunu ortaya çıkarmıştır.

Diğer yandan öğretmenlerin uzaktan eğitim sürecinde ev yaşamı ve aile düzeniyle ilgili sorunlar yaşadıkları da tespit edilmiştir. Ev yaşamı ve aile düzeni teması altında yaşanılan sorunlar; "ebeveyn rolü, eş (öğretmen), evin düzeni, kendi" alt temaları altında belirtiilmiştir. Araştırma sonucu ebeveyn olan öğretmenlerin uzaktan eğitim sürecinde rol karmaşası yaşadıkları sonucuna ulaşılmıştır. Bu süreçte çocuğu öğrenci olan öğretmenlerin çocuğunun uzaktan eğitim dersleri ile ilgilenmek, çocuğu küçük olan öğretmenlerin ise çocuğunun bakım ve ihtiyaçları ile ilgilenmek durumda kaldığı gözlemlenmiştir. Öyle ki öğretmenlerin ev ortamında derslerini yürüttükleri için bu süreçte ebeveyn rolünün gerektirdiği sorumlulukları da yerine getirmek durumunda kaldıkları, bu bağlamda da süreç içerisinde zorluklar yaşadıkları tespit edilmiştir. Yine uzaktan eğitim sürecinde ev ortamında derslerin yürütülmesinin evde gerçekleştirilecek kahvaltı, temizlik gibi aktivitelerin zamanlamasında değişiklikler meydana getirdiği, bu eylemlerin ders saatlerine göre yeniden düzenlendiği tespit edilmiştir. Bu durum uzaktan eğitim sürecinin, öğretmenlerin ev düzenlerini de 
etkilendiğini göstermektedir. Araştırmada ulaşılan sonuçlardan biri de uzaktan eğitim sürecinin öğretmenlerin kendisini de doğrudan etkilemesidir. Bu bağlamda öğretmenlerin derslerin yoğun olması nedeniyle günlük hayatlarını planlayamadıkları, mesai kavramının ortadan kalktığı, uzun saatler boyunca veliler ile öğrencilerin sorularına cevap vermek durumunda kaldıkları ve rol karmaşası yaşadıkları sonucuna ulaşılmıştır. Yine araştırmaya katılan öğretmenlerin ifadesi ile bekar öğretmenlerin ve uzaktan eğitim derslerini okulda yürüten öğretmenlerin kendi ve aile hayatlarının olumsuz anlamda süreçten etkilenmediği sonucuna da ulaşılmıştır.

Araştırma sonucunda uzaktan eğitim sürecinde problem yaşayan öğretmenlerin yaşadıkları problemlere bazı çözüm yolları bulduğu da görülmüştür. Örneğin; öğrencileriyle iletişimde kalmak isteyen öğretmenler bazı çevrimiçi uygulamaları kullanarak sınıf grupları oluşturmuşlardır. Uzaktan eğitim için kullandıkları çevrimiçi programların katılımcı, dosya paylaşımı, zaman gibi sınırlılıkları ortaya çıktığında farklı uygulamalara yönelmişlerdir. Öğrencilerin ders sırasında aktif katılımlarını sağlamak için mikrofonlarının açı olmasını sağlamışlardır. Karşılaşılan sorunların çözümü amacıyla da velilerle, diğer öğretmenlerle ve okul yöneticileriyle sürekli iletişim halinde kaldıkları tespit ediilmiştir.

Sonuç olarak; tüm dünyayı etkisi altına alan Covid 19 pandemisinde acil ihtiyaç olarak ortaya çıkan uzaktan eğitim kapsamında derslerini yürüten öğretmenler yukarıda da ifade edilen birçok sorun yaşamış ve süreç içerisinde yaşadıkları sorunlara çözüm bularak bu sorunların ders işleme sürecine etkisini azaltmaya çalışmışlardır.

\section{ÖNERILER}

Bu çalışmada çıkan sonuçlara dayalı olarak şu öneriler getirilebilir:

1. Öğrencilere pandemi sürecinde kaymakamlık, belediye, sivil toplum kuruluşları tarafından yapılan teknolojik araç-gereç desteği arttırılarak devam ettirilmeli ve öğrencilerin teknik donanım eksiklikleri giderilerek öğrenciler arasındaki imkân eşitliği sağlanmalıdır.

2. Uzaktan eğitim sisteminde kullanılan sistemler altyapı ve teknik olarak güçlendirilerek ders işleme sürecinin devamı sağlanmalıdır.

3. Uzaktan eğitim sürecinde öğretmenlerin derslerinde kullanabilecekleri dijital içerik ve etkinlikler üretilerek öğretmenler bu konuda desteklenmelidir.

4. Öğretmenlere çevrimiçi eğitim, uzaktan eğitim, web 2.0 araçları konularında eğitimler vererek mevcut bilgi düzeyini artırmaya yönelik çalışmalar yapılmalıdır.

5. Öğrenci ve velilere çevrimiçi programların kullanımı ile ilgili eğitimler vererek mevcut bilgi düzeyini artırmaya yönelik çalışmalar yapılmalıdır.

6. Eğitim sürecinin önemli bir öğesi olan veliler bu süreçte eğitim ve seminerlerle bilgilendirilerek desteklenmelidir.

7. Öğretmenlerin motivasyonlarını arttırmak amacıyla, pandemi kuralları dikkate alınarak piknik, müzik dinletisi gibi sosyal etkinlikler ve aktiviteler planlanlanmalıdır.

8. Veli ile iletişim arttırılarak uzaktan eğitim ile yapılan derslere öğrenci katılımının artırılması ve devamının sağlanması için velinin sürece katılımı sağlanmalıdır. 
9. Uzaktan eğitimde ders saatleri düzenlenirken öğretmenlerin aile hayatlarında esneklik oluşturabilecek zamanlamalara dikkat edilmelidir.

10. Öğretmenler uzaktan eğitim kapsamında derslerini yürütürken, evde bulunan çocuklarının vakitlerini değerlendirebilecekleri dijital platformlar, dijital içerikler ve basılı materyaller hazırlanmalıdır.

\section{KAYNAKÇA}

Akbaba, S . (2010). Eğitimde motivasyon. Atatürk Üniversitesi Kazım Karabekir Eğitim Fakültesi Dergisi, (13), 343-361.

Akgül, G. ve Oran, M. (2020). Sosyal bilgiler öğretmenlerinin, ortaokul öğrencilerinin ve öğrenci velilerinin pandemi sürecindeki uzaktan eğitime ilişkin görüşleri. Eğitimde Yeni Yaklaşımlar Dergisi, 3(2) , 15-37.

Alea, L., Fabrea, M., Roldan, R. ve Farooqi, A. (2020). Teachers' Covid-19 awareness, distance learning education experiencesand perceptionstowards institutional readiness and challenges. International Journal of Learning, Teachingand Educational Research, 19(6), 127144 .

Alkan, C. (2011). Eğitim teknolojisi. Ankara: Anı Yayıncılık.

Avcı, F. ve Akdeniz, E. (2021). Koronavirüs (Covid-19) salgını ve uzaktan eğitim sürecinde karşılaşılan sorunlar konusunda öğretmenlerin değerlendirmeleri. Uluslararası Sosyal Bilimler ve Eğitim Dergisi, 3(4). 117-154.

Aydemir, A. (2021). Uzaktan eğitim sürecinde öğretmen ile öğrenci-veli iletişimi: Sosyal bilgiler öğretmenlerinin deneyimleri. Sosyal Araştırmalar Dergisi, 2(10), 813-827.

Bakioğlu, B. ve Çevik, M. (2020). Covid-19 pandemisi sürecinde fen bilimleri öğretmenlerinin uzaktan eğitime ilişkin görüşleri. TurkishStudies, 15(4), 109-129.

Balaman, T. ve Hanbay Tiryaki, S. (2021). Corona virüs (Covid-19) nedeniyle mecburi yürütülen uzaktan eğitim hakkında öğretmen görüşleri. İnsan ve Toplum Bilimleri Dergisi, 10(1), 52-84.

Baş, T. ve Akturan U. (2008). Nitel araştırma yöntemleri Nvivo 7.0 ile nitel veri analizi. Ankara: Seçkin Yayıncılık.

Başkale, H. (2016). Nitel araştırmalarda geçerlik, güvenirlik ve örneklem büyüklügünün belirlenmesi. Deuhfed, 9(1), 23-28.

Büyükkaragöz, S., Muşta, M., Yılmaz, H. ve Pilten, Ö. (1997). Eğitime giriş. Ankara: Güray Ofset.

Büyüköztürk, Ş., Akgün, Ö., Karadeniz Ş, Demirel, F. ve Kılıç Çakmak, E. (2020). Eğitimde bilimsel araştırma yöntemleri. Ankara: PegemAkedemi. 
Çakın, M. ve Külekçi Akyavuz, E. (2020). Covid-19 süreci ve eğitime yansıması: Öğretmen görüşlerinin incelenmesi. International Journal of Social Sciencesand Education Research, 6(2), $165-186$.

Canbolat U. ve Yıldırım Y. (2021). Ortaokul öğretmenlerinin Covid-19 salgın sürecinde uzaktan eğitim deneyimlerinin incelenmesi. Açıöğretim Uygulamaları ve Araştırmaları Dergisi, 7(1), 74-109.

Demirel, Ö. (2020). Eğitim sözlü̆̆̈̈̈. Ankara: Pegem Akademi.

Durisic, M. ve Bunijevac, M. (2017). Parental İnvolvement as an important factorfor successfu leducation. Ceps Journal, 7(3), 137-153.

Ergüç Şahan, B. ve Parlar, H. (2021). Pandemi döneminde sınıf öğretmenlerinin karşılaştığ1 problemler ve çözüm yolları. Uluslararası Toplum Araştırmaları Dergisi, 18(40), 2327-2407.

Erkoca, M. (2021). Uzaktan eğitim sürecinde öğrenci ilgisi bir çalışma. Açıköğretim Uygulamaları ve Araştırmaları Dergisi, 7(1) , 148-163.

Ersoy, A. F. (2016). Eğitimde nitel araştırma desenleri. Ankara: Anı Yayıncılık.

Ezer, F. ve Aksüt, S. (2021). Covid-19 sürecinde sosyal bilgiler dersinde Eğitim Bilişim Ağ1 platformunu kullanmaya yönelik sosyal bilgiler öğretmenlerinin görüşleri. İnönü Üniversitesi Ĕ̆itim Fakültesi Dergisi, 22(1), 197-233.

Fidan, M. (2020). Covid-19 belirsizliğinde eğitim: İlkokullarda zorunlu uzaktan eğitime ilişkin öğretmen görüşleri. Uşak Üniversitesi Eğitim Araştırmaları Dergisi, 6(2), 24-43.

Güneş, F . (2014). Eğitimde ödev tartışmaları. Bartın University Journal of Faculty of Education, $3(2), 1-25$.

Kabapınar, Y., Kanyılmaz, B., Ören Koçhan, N. ve Atik, U. (2021). Öğretmen ve velilerin gözünden öğrencilerin uzaktan eğitime katılmalarının öyküleri: “Uzaktan eğitimi mi, uzakta kalan eğitim mi?" Temel Ĕ̆itim Araştırmaları Dergisi, 1(1), 79-98.

Karaca, İ., Özcan, M., Karaca, N. ve Karamustafaoğlu, N. (2021). Öğretmenlerin uzaktan eğitimin yararına ilişkin algılarının incelenmesi. Humanistic Perspective , 3(1), 209-224 .

Kavuk, E., ve Demirtaş, H. (2021). Covid-19 pandemisi sürecinde öğretmenlerin uzaktan eğitimde yaşadığı zorluklar. E-Uluslararası Pedandragoji Dergisi, 1(1), 55-73.

Kaya, Z. (2002). Uzaktan eğitim. Ankara: Pegem Akademi.

Kaymaz, A . (2021). Uzaktan eğitim sürecinde değişen iş yükü ve etkilerine ilişkin öğretmen görüşleri. Uluslararası Liderlik Eğitimi Dergisi, 1(1) , 91-105 .

Kazu, İ., Bahçeci, F. ve Kurtoğlu Yalçın, C. (2021). Öğretmenlerin koronavirüs pandemisi döneminde verdikleri uzaktan eğitime ilişkin metaforik algıları. Fırat Üniversitesi Sosyal Bilimler Dergisi, 31(2) , 701-715.

Keskin, Y. (2020). Sosyal bilgiler programı tarihi ve güncel gelişmeler. Ankara: Pegem Akademi.

Kurt, K., Kandemir, M. ve Çelik, Y . (2021). Covid-19 pandemi sürecinde uzaktan eğitime ilişkin sınıf öğretmenlerinin görüşleri. Türkiye Bilimsel Araştırmalar Dergisi, 6(1) , 88-103. 
Lassoued Z., Alhendawi M. ve Bashitialshaaer R. (2020). An exploratory study of the obstaclesfor achieving quality in distance learning duringthe covid-19 pandemic. EducationSciences, 10(9), 232.

MEB. (2018). 20 Nisan 2021 tarihinde https://mufredat.meb.gov.tr/Dosyalar/2018 adresinden erişildi.

MEB. (2020). 2019-2020 eğitim öğretim yılı sene sonu iş ve işlemleri (Sayı: 7646231). 20 Nisan 2021 tarihinde https://www.maarifmevzuati.com/ https://mufredat.meb.gov.tr/Dosyalar/2018 adresinden erişildi.

MEB. (2020). 31 Ağustos 2020 tarihinde başlayacak "eğitim programı" (Sayı: 11215393). 20 Nisan 2021 tarihinde https://www.maarifmevzuati.com/adresinden erişildi.

MEB. (2020). Bazı eğitim faaliyetlerinin durdurulması (Sayı: 5964251). 20 Nisan 2021 tarihinde https://www.maarifmevzuati.com/ adresinden erişildi.

MEB. (2020). Covid-19 Salgın Döneminde Ölçme ve Değerlendirme Uygulamaları (Sayı:15680395). 20 Nisan 2021 tarihinde https://www.maarifmevzuati.com/ adresinden erişildi.

MEB. (2020). İdari izin (Sayl: 5497866). 20 Nisan 2021 tarihinde https://www.maarifmevzuati.com/ adresinden erişildi.

MEB. (2020). İdari İznin Uzatılması (Sayı: 6668482). 20 Nisan 2021 tarihinde https://www.maarifmevzuati.com/ adresinden erişildi.

MEB. (2020). İdari İznin Uzatılması (Sayı: 7193697). 20 Nisan 2021 tarihinde https://www.maarifmevzuati.com/ adresinden erişildi.

MEB. (2020). Ölçme ve Değerlendirme Uygulamaları (Sayı: 18443982). 20 Nisan 2021 tarihinde https://www.maarifmevzuati.com/ adresinden erişildi.

MEB. (2020). Ortaokul ve İmam Hatip Ortaokullarının 5. Sinıflarında Yüz Yüze Eğitim (Sayı: 15473721). 20 Nisan 2021 tarihinde https://www.maarifmevzuati.com/ adresinden erişildi.

MEB. (2020). Yüz Yüze Eğitime Ara Verilmesi (Sayı: 16964289). 20 Nisan 2021 tarihinde https://www.maarifmevzuati.com/ adresinden erişildi.

MEB. (2020). Yüz Yüze Eğitime İlişkin Açılamalar (Sayı: 13044945). 20 Nisan 2021 tarihinde https://www.maarifmevzuati.com/ adresinden erişildi.

MEB. (2020). Yüz Yüze ve Uzaktan Eğitim (Sayı: 14430520). 20 Nisan 2021 tarihinde https://www.maarifmevzuati.com/ adresinden erişildi.

MEB. (2021). 20202021 Eğitim Öğretim Yılı Faaliyetleri (Sayı: 26439762). 20 Nisan 2021 tarihinde https://www.maarifmevzuati.com/ adresinden erişildi.

MEB. (2021). İkinci Dönem Sınav Uygulamaları (Sayı: 22992597). 20 Nisan 2021 tarihinde https://www.maarifmevzuati.com/ adresinden erişildi.

MEB. (2021). Uzaktan Ĕ̆itim Faaliyetleri (Sayı: 24784685). 20 Nisan 2021 tarihinde https://www.maarifmevzuati.com/ adresinden erişildi. 
MEB. (2021). Yüz Yüze Eğitim Uygulamaları (Sayı: 20218459). 20 Nisan 2021 tarihinde https://www.maarifmevzuati.com/ adresinden erişildi.

MEB. (2021). Yüz Yüze ve Uzaktan Ĕ̈itim Uygulamaları (Sayı: 25849323). 20 Nisan 2021 tarihinde https://www.maarifmevzuati.com/ adresinden erişildi.

Morgan, H. (2020). Best practicesfor implementing remote learning during a pandemic. The Clearing House: A Journal of Educational Strategies, Issues and Ideas, 93(3), 135-141.

Oyedotun, T. (2020). Suddenchange of pedagogy in education driven by Covid-19: Perspectives and evaluation from a developing country. Research in Globalization, 2, 1-5.

Parker, W. C. (2018). İlkokul ve ortaokullarda sosyal bilgiler eğitimi. Filiz Zayimoğlu Öztürk, Selçuk Beşir Demir (çev.). Ankara: Pegem Akademi.

Patton, M. K. (2018). Nitel araştırma ve değerlendirme yöntemleri. Mesut Bütün, Selçuk Beşir Demir (çev.). Ankara: Pegem Akademi.

Sayg1, H. (2021). Covid-19 pandemi uzaktan eğitim sürecinde sınıf öğretmenlerinin karşılaştı̆̆ı sorunlar. Açıköğretim Uygulamaları ve Araştırmaları Dergisi, 7(2), 109-129.

Seyhan, A. (2021). Sosyal bilgiler öğretmen adaylarının covid-19 salgını sürecinde uzaktan eğitim deneyimleri ve görüşleri . Açıöğretim Uygulamaları ve Araştırmaları Dergisi, 7(3) , 65-93.

Sezgin, S. (2021). Çevrimiçi dersler için motivasyonel yaklaşım ve uygulamalar. Ankara: Anı Yayıncilık.

Yavuz, M. (2018). Eğitim bilimine giriş. Ankara: Anı Yayıncılık.

Yeşilyurt, S. ve Dündar, R. (2020). Sosyal bilgiler öğretmenlerinin eğitim bilişim ağı özelinde uzaktan eğitime bakış açlarının değerlendirilmesi. International Journal of Social Science Research, 9(1) , 79-95.

Yılar, M. B. ve Tağrıkulu, P. (2020). Sosyal bilgilerde öğrenme ve öğretim yaklaşımları. Ankara: Pegem Akademi.

Yıldırım, A. ve Şimşek, H. (2013). Sosyal bilimlerde nitel araştırma yöntemleri. Ankara: Seçkin Yayıncilik.

Yıldızlar, M. (2018). Öğretim ilke ve yöntemleri. Ankara: Pegem Akademi. 